\title{
„Dzisiaj ma głos towarzysz Mauzer”. Rewolucyjna strategia literacka Majakowskiego
}

\author{
Xawery Stańczyk
}

\begin{abstract}
Abstrakt: Włodzimierz Majakowski, rosyjski poeta futurystyczny, krytykowany był nie tylko przez krytyków i pisarzy o poglądach konserwatywnych lub umiarkowanych, lecz również przez ideologów oraz aktywistów bolszewickich. Autorzy o poglądach umiarkowanych wyrażali dezaprobatę wobec zaangażowania Majakowskiego w ruch komunistyczny i obawiali się, że geniusz się marnuje. Z kolei lewicowo nastawieni pisarze odmawiali Majakowskiemu miejsca pośród proletariuszy w związku z jego nieodpowiednim pochodzeniem. Niniejszy artykuł pokazuje podobieństwa łączące oba rodzaje krytyki, zawiera również próbę odpowiedzi na pytanie, dlaczego partia komunistyczna wykazywała tak daleko idącą wrogość w stosunku do awangardowej poezji rewolucyjnej.

Celem artykułu było znalezienie odpowiedzi na pytanie, dlaczego literaturę zaangażowaną odbiera się jako nieszczerą, nieprzyzwoitą i nienaturalną, jak też przeanalizowanie relacji pomiędzy słowami poety, ich szczególną mocą performatywną, rewolucyjnym nadużyciem oraz utopijną wizją nowego świata.

Wyrażenia kluczowe: rewolucja, konflikt, słowo, literatura, utopia, nadużycie rewolucyjne, utopijna wizja nowego świata
\end{abstract}

Na początku lat dwudziestych XX wieku Włodzimierz Majakowski, futurystyczny poeta i zdeklarowany zwolennik rewolucji, przygotował na jej cześć poemat 150000000. Tytułowe sto pięćdziesiąt milionów to mieszkańcy nowej, radzieckiej Rosji - Majakowski uczynił ich nie tylko zbiorowym bohaterem, lecz także autorem dzieła, rezygnując z podpisywania go nazwiskiem „niewielkiego ułamka” spośród ogółu nowego społeczeństwa. Ukończony poemat przesłał „z komfutowskim pozdrowieniem” (Komfut to komunistyczno-futurystyczny komitet artystów i pisarzy) stojącemu na czele państwa Włodzimierzowi Leninowi.

Przeczytawszy nadesłane dzieło, Lenin sporządził następującą notatkę:

„Jak nie wstyd głosować za wydaniem 150000000 Majakowskiego w 5000 egz.?

Absurd, głupota, wierutna bzdura i pretensjonalność.

Moim zdaniem, trzeba drukować spośród takich rzeczy zaledwie 1 na 10

i nie więcej niż 1500 egz. dla bibliotek i dziwaków.

A Łunaczarskiego wychłostać za futuryzm.

Lenin"1

W odpowiedzi na tę kartkę jej adresat, Anatolij Łunaczarski, ludowy komisarz oświaty, argumentował, że jemu dzieło się podoba podobnie jak poecie Walerijowi Briusowowi oraz robotnikom, którym Majakowski czytał poemat przed publikacją ${ }^{2}$. Jednakże takie

1 Włodzimierz Lenin do Anatolija Łunaczarskiego w kartce z 6 maja 1921 roku (Puścizna literacka, t. 65: Nowe o Majakowskim, Moskwa 1958, cyt. za: Woroszylski, 1965, s. 379; rozstrzelenie X.S.).

2 Anatolij Łunaczarski na odwrocie kartki od Lenina (Puścizna literacka, t. 65: Nowe o Majakowskim, Moskwa 1958, cyt. za: Woroszylski, 1965, s. 379). 
usprawiedliwienia nie miały szans przekonać Lenina, którego myśli zaprzątały wówczas znacznie poważniejsze problemy: wskutek wojny domowej i „komunizmu wojennego” w opustoszałych miastach (większość mieszkańców Moskwy i Piotrogrodu w poszukiwaniu żywności przeniosła się na wieś) panował głód, raz po raz wybuchały strajki i protesty. Apogeum tych protestów było powstanie marynarzy w Kronsztadzie. Ich hasła i postulaty okazały się zbieżne z wizją rewolucji w poezji Majakowskiego. Narastający z różnych stron gniew społeczny może częściowo tłumaczyć wściekłość Lenina na przesłany poemat; wściekłość, która nie ustawała: wódz bolszewików zwracał się w sprawie poematu do państwowego wydawnictwa Gosizdat:

„Czy nie można temu zapobiec? Trzeba temu zapobiec. Umówmy się, że będziemy drukowali tych futurystów nie częściej niż 2 razy do roku i nie więcej niż 1500 egz."3

Lenin dopytywał jeszcze, czy nie można by znaleźć jakichś „antyfuturystów”, a według relacji Nikołaja Mieszczeriakowa, redaktora naczelnego Gosizdatu, nazwać miał postawę Majakowskiego „komunizmem chuligańskim”. Sławiący rewolucję poemat wydany w niewielkim nakładzie pięciu tysięcy egzemplarzy wywołał jednoznacznie negatywną, emocjonalną i zajadłą reakcję przywódcy bolszewików.

\section{„Autentyczny talent”}

Majakowskiego krytykowali wielokrotnie krytycy literaccy, pisarze i obserwatorzy życia kulturalnego za ideowe zaangażowanie po stronie rewolucji i komunizmu. Czesław Miłosz bulwersował się: „Majakowski jako nauczyciel? Wszystkie zmory wypełzają z kątów, słyszy się głos Pankracego z Nie-Boskiej komedii" (cyt za: Parniewski, 1995, s. 147). Borys Pasternak uznał poemat 150000000 za „nietwórczy” i - jak pisze autor biografii Majakowskiego, Bengt Jangfeldt - „zastanawiał się, dlaczego poeta postanowił trwonić talent na sprawy dotyczące gospodarki narodowej, równowagi budżetowej itp." (Jangfeldt, 2010, s. 192). Postawa Majakowskiego była, według Pasternaka, naiwna i głupia, wręcz nonsensowna, a w dodatku ograniczała wrodzony talent poety (Jangfeldt, 2010, s. 375). Wiaczesław Połonski, redaktor naczelny umiarkowanego pisma „Nowyj Mir” uważał, że teoretyzowanie, członkostwo w ugrupowaniu artystycznym (wówczas był to LEF) i wybujałe ambicje negatywnie odbijały się na poziomie twórczości Majakowskiego, która swą moc czerpała z indywidualnego talentu (W. Połonski, Uwagi dziennikarza. LEF czy Bluff?, „Izwiestia” z 25/27 lutego 1927 roku, cyt. za: Woroszylski, 1965, ss. 587-591); wypełnianie zamówień publicznych nie służyło ani socjalizmowi (proletariat i tak nie uznałby pisarzy pochodzących z innych klas społecznych), ani literaturze (ta rozwijała się dzięki krytyce i buntowi) (Jangfeldt, 2010, s. 374). Co gorsza, Majakowski jako „autentyczny talent”, którego rola w poezji była „wielka” w czasie jego „egocentrycznego” buntu, nie tylko nie porzucił „grzechów młodości”, ale jeszcze „przyoblekał się w togę ideologa proletariatu”

3 Włodzimierz Lenin do Michaiła Pokrowskiego (Puścizna literacka, t. 65: Nowe o Majakowskim, Moskwa 1958, cyt. za: Woroszylski, 1965, s. 379; rozstrzelenie X.S.).

4 Wypowiedź Lenina cytowana we wspomnieniach Nikołaja Mieszczeriakowa (Puścizna literacka, t. 65: Nowe o Majakowskim, Moskwa 1958, cyt. za: Woroszylski, 1965, s. 380). 
i „podejmował się obrony kultury komunistycznej przed komunistami”; to ostatnie - dowodził Połonski - dopełniało nieszczęścia Majakowskiego (W. Połonski, Bluff trwa, „Nowyj Mir" nr 5 z maja 1927 roku, cyt. za: Woroszylski, 1965, ss. 597-600).

Uzupełnieniem i zarazem konsekwencją krytyki niesłusznych poglądów poety była krytyka poziomu jego otwarcie politycznych dzieł. Dostrzec w niej można kontynuację wcześniejszych uwag, atakujących przede wszystkim otwarcie poezji na mowę potoczną i tematy nieprzystające do wyobrażenia o podniosłej sztuce słowa. Mimo towarzyszącego od początku potępienia ze strony stojących na straży czystości poezji i języka poetyckiego recenzentów, Majakowski zdobył pewną popularność jeszcze przed rewolucją. Tak wspominat to pisarz Korniej Czukowski:

„Miał dwadzieścia dwa lata. Stał na progu wielkich dokonań. Postępowa młodzież tych czasów admirowała go już gorąco, ale ludzie starszego pokolenia przeważnie odnosili się do jego nowatorstwa nieprzyjaźnie, wręcz wrogo, bo, jak im się zdawało, ten śmiały nowator gwałcił swoimi wierszami szczytne tradycje dawnej sztuki" (Czukowski, 1966, s. 78).

Uwielbienie młodzieży i lekceważący stosunek wielu pisarzy i komentatorów towarzyszyły Majakowskiemu do końca życia, przy czym wydaje się, że krytyka skupiała się raczej na politycznych niż lirycznych wypowiedziach poetyckich Majakowskiego. Udzielała się ona zresztą i późniejszym autorom - Bengt Jangfeldt pisał o Misterium-buffo:

„Misterium... to ciekawy utwór w dorobku autora, lecz nie dzieło znaczące. Koncepcyjnie bliski naiwnym wyobrażeniom proletariackich poetów, dla których nie istniał lepszy sposób ukazania przyszłej komuny niż za pomocą starego biblijnego obrazu raju, nie był więc przykładem sztuki awangardowej, której Majakowski hołdował" (Jangfeldt, 2010, s. 155).

Podobną ocenę Jangfeldt wystawia innemu zaangażowanemu politycznie utworowi Majakowskiego, poematowi Włodzimierz Iljicz Lenin, który według szwedzkiego badacza był „nierówny”, gdyż fragmenty epickie są „za długie i zbyt szczegółowe”, a hołd partii cechuje się „pustą retoryką” (Jangfeldt, 2010, s. 270).

Tego rodzaju opinie swój najdobitniejszy bodaj wyraz znalazły w artykule Osipa Mandelsztama w miesięczniku „Rossija” z 1922 roku:

„Majakowski rozwiązuje tu elementarny i wielki problem «poezji dla wszystkich, nie zaś dla wybranych». Ekstensywne rozszerzenie pola pod poezję odbywa się, naturalnie, kosztem intensywności, treściwości, kultury poetyckiej. Doskonale obznajmiony z bogactwem i skomplikowaniem poezji światowej, Majakowski, zapoczątkowując swoją «poezję dla wszystkich», musiał posłać do diabła wszystko niezrozumiałe, czyli zakładające minimalne przygotowanie poetyckie słuchacza. Jednakże zwracanie się wierszem do całkowicie nie przygotowanego poetycko słuchacza to zadanie tak samo niewdzięczne jak próba wbicia się na pal. Całkiem nie przygotowany zupełnie nic nie zrozumie albo też wyzwolona od wszelkiej kultury poezja przestanie być poezją i wtedy dopiero, dzięki dziwnej właściwości natury ludzkiej, stanie się dostępna dla nieogarnionych rzesz słuchaczy. Majakowski jednak pisuje wiersze, i to wiersze wielce kulturalne. [...] Szkoda więc, że tak zubaża sam siebie [...]" (cyt. za: Woroszylski, 1965, ss. 394-395). 


\section{„Majakowszczyzna” na tawie oskarżonych}

Ciekawsze od refutacji dokonywanej przez autorów umiarkowanych i klasycyzujących są systematyczne ataki, które futurystów, a w szczególności Majakowskiego, spotykały ze strony ideologów i działaczy bolszewickich. Poetyka futuryzmu nigdy nie była bliska partii, niemniej po przejęciu władzy bolszewicy próbowali przeciągnąć na swoją stronę lewicową w znakomitej mierze rosyjską awangardę, otwierając jej szersze niż uprzednio pole działania. Sytuacja zaczęła się zmieniać już w 1919 roku, gdy partia dostrzegła w twórczości futurystów konkurencyjną wizję komunistycznego społeczeństwa. Odebrała im możliwość przygotowania dekoracji na oficjalne uroczystości, a co gorsza - możliwość wydawania własnych czasopism. Awangarda straciła wpływ na politykę kulturalną prowadzoną przez Ludowy Komisariat Oświaty.

Samemu Majakowskiemu - tak samo jak przed rewolucją - zarzucano „niezrozumiałość”, tym razem dodając wszelako: „dla mas” lub „dla robotników”. Taki był kierunek krytyki, która dotknęła Misterium-buffo, sztukę, za pomocą której Majakowski próbował zbliżyć się do linii bolszewików w rok po przejęciu przez nich władzy. Poeta napisał później nową wersję utworu, ale Gosizdat - zgodnie z poleceniem Lenina, by Majakowskiego nie publikować - nie przyjął do druku tego utworu. W późniejszych latach Majakowski nieustannie zmagat się z niechęcią ze strony państwowego wydawnictwa, a wygrany przez poetę proces o niewypłacone honorarium bynajmniej nie polepszył relacji ani z Gosizdatem, ani z partią. Jak zauważył Jangfeldt:

„Tego samego dnia, kiedy sąd wydał orzeczenie, na pierwszej stronie «Prawdy» ukazał się artykuł zatytułowany Dość majakowszczyzny! Jego autorem był jeden z wysokich działaczy partyjnych, Lew Sosnowski (członek prezydium partii kierujący biurem propagandy, Agitpropem). Artykuł kończył się słowami: «Miejmy nadzieję, że już wkrótce na ławę oskarżonych trafi majakowszczyzna»" (Jangfeldt, 2010, s. 158).

„Prawda” była dziennikiem partyjnym, a artykuł autorstwa tak prominentnej postaci stanowił czytelny sygnał, że decyzja o ignorowaniu Majakowskiego przez wydawców zapadła na szczytach władzy. Negatywne zdanie Lenina o futurystach podzielała jego żona, Nadieżda Krupska. W lutym 1921 roku uznała na łamach „Prawdy” ich twórczość za „propagowanie najgorszych elementów dawnej sztuki oraz [...] skrajnie nienormalnych, wypaczonych uczuć" (cyt. za: Jangfeldt, 2010, s. 188). Zarzuty dekadencji, skandaliczności, „niezrozumiałości” i indywidualizmu padały pod adresem Majakowskiego w ogromnej mierze ze strony tak zwanych pisarzy proletariackich, czyli ruchu Proletkultu. Stanowisko Lenina wyrażone w cytowanej na początku notatce było zresztą powszechnie znane. Wiedział o nim także Majakowski: w poemacie Czwarta Międzynarodówka (niekiedy występującym pod tytułem Piąta Międzynarodówka) przedstawił Lenina jako pomnik, który zajęty jest staniem na cokole za murami Kremla, a na widok poety myśli, że należałoby go wychłostać. 
Krytyka dobiegała też z kręgów bliższych Majakowskiemu. Nikołaj Czużak, krytyk związany z prowadzonym przez Majakowskiego pismem „LEF”, na łamach tegoż pisma (nr 2 z kwietnia-maja 1923 roku) wytykał poecie liryzm i indywidualizm w poemacie $O$ tym:

„Sentymentalny romans. [...] Gimnazistki obleją go łzami. [...] Ale nas, którzy znamy u Majakowskiego coś innego i w ogóle znamy dużo innych rzeczy, w 1923 roku ani trochę to nie wzrusza. [...]

Kiedy w roku 1914 liryczny «Majakowski», rozwścieczony, rozmawiał za pan brat z «Panem Bogiem» - brzmiało to zuchwale, a nawet dumnie... Niechby nawet byt to jeszcze indywidualizm, ale - indywidualizm heroiczny. Od tego czasu [...] - po pierwsze, dużo się zmieniło, a co najważniejsze - «bohaterowie i tłum» zamienili się miejscami. [...]

I jeszcze ostatnia sprawa: w finale poematu ponoć «jest wyjście». Wyjściem tym ma być wiara, że «w przyszłości wszystko będzie inaczej», nastąpi jakieś «zdumiewające życie». [...]

Sądzę, że to wiara desperacji, wynikająca $z$ «nie ma gdzie się podziać» $\mathrm{i}$ - bardzo odległa od rzeczowych wizji roku czternastego. Nie wyjście, lecz bezwyjściowość" (cyt. za: Woroszylski, 1965, s. 438; rozstrzelenie X.S.).

Czużak krytykował indywidualizm i uczuciowość Majakowskiego nieprzystające do bolszewickiej ideologii, a także wiarę w jakąś odległą, lepszą przyszłość - wiarę, która oznaczała wszak odrzucenie radzieckiej teraźniejszości i zwątpienie w poprawę jakości życia wskutek polityki bolszewików. Co jednak najciekawsze, tym niezgodnym z partyjną linią przekonaniom Czużak przeciwstawiał wczesne wiersze poety jako bardziej szczere i prawdziwe w „heroicznym” indywidualizmie. Jeśli zatem Majakowski nie mógł być poprawny ideologicznie, powinien był trwać w swoim indywidualizmie, przenikliwy i autentyczny jak dawniej. Można by ten wywód ciągnąć dalej: skoro Majakowski nie potrafit pisać zgodnie z wytycznymi partii, powinien był pozostać wierny swojemu „autentycznemu talentowi”. W ten sposób, nie oddalając się zbytnio od słów Czużaka, za retoryką marksistowską zobaczyć można stare, mieszczańskie przekonania o „talencie”, „uzdolnieniu” i „autentyczności”, za retoryką materialistyczną - idealizm. Podobne wnioski można wyciągnąć z wypowiedzi nieprzychylnych Majakowskiemu proletkultowców: za zarzutem odstępstwa od bolszewickiej ortodoksji i posługiwania się językiem niezrozumiałym dla robotników następowało żądanie „szczerej”, indywidualnej ekspresji. Jangfeldt cytuje recenzenta z charkowskiej gazety „Proletarij”, według którego pisany przez Majakowskiego jesienią 1927 roku rewolucyjny poemat Dobrze! „zawodzi całkowicie i częstokroć nie wznosi się ponad poziom przeciętnej publicystyki. Poeta może się irytować, może z tym walczyć, ale swojej «lirycznej konstytucji» najwidoczniej nie jest w stanie przezwyciężyć" (Jangfeldt, 2010, s. 365).

Dla Majakowskiego obracającego się w kręgu formalistów kwestie takie, jak „szczerość” czy „autentyczność” (używam cudzysłowu, by podkreślić historyczną konwencjonalność tych zbyt często naturalizowanych pojęć), miały w literaturze znaczenie drugorzędne: słowo było materią, którą się formowało i za pomocą której formowało się życie, a nie ezoterycznym przejawem jakiejś „lirycznej konstytucji”. Sens pracy literackiej wyznaczał 
jej cel, stosunek do rzeczywistości. Pierwszorzędną sprawą było to, o czym się pisze, a nie: jak się pisze, z czego w formie anegdoty zdał relację młodszy poeta, Nikołaj Asiejew ${ }^{5}$. Jako zdeklarowany komunista autor Obłoku w spodniach afirmowat etos robotniczy w swoich wierszach i poematach; nie tyle głosił w nich chwałę rewolucji, ile uczestniczył w niej za pomocą słowa. Robotniczy charakter poezji wynikać miał nie z pochodzenia społecznego autora czy z posługiwania się rejestrami językowymi typowymi dla klasy robotniczej jakkolwiek włączanie elementów mowy potocznej było istotną cechą koncepcji języka poetyckiego Majakowskiego - lecz z podobieństwa pracy literackiej i pracy w fabryce. Poetę i robotnika postrzegał tak samo - jako wyspecjalizowanych pracowników, na której to analogii opierała się idea solidaryzmu awangardy artystycznej i klasy robotniczej. Tymczasem dla Proletkultu zrównanie poety i robotnika prowadzić miało do uwspólnienia języka jako kodu komunikacyjnego i rzeczywistej wymienności ról. Upraszczając, można powiedzieć, że Majakowski pragnął pociągnąć robotników ku nowej, „odczarowanej” kulturze, natomiast proletkultowcy podsuwali im zwierciadło dawnej, bardziej zrozumiałej i powszechniej akceptowanej kultury. W trakcie tej konfrontacji futurystom przypinano często etykietę ich głównego - w ich własnych deklaracjach - wroga, czyli burżuazji. Przypisanie zaś tożsamości mieszczańskiej (burżuazyjnej), czy raczej napiętnowanie tą tożsamością, ułatwiło przeciwnikom futurystów publiczne nadawanie swoim adwersarzom wszelkich negatywnych cech rozmaicie rozumianego mieszczaństwa.

\section{Rugowanie awangardy}

Krytyka politycznego zaangażowania Majakowskiego, jaka płynęła od osób dystansujących się wobec komunizmu, w szczególności z kręgów literackich, wydaje się dość zrozumiała jako reakcja na naruszenie zasad neutralności i indywidualnego „talentu”, które - choć same w sobie pozostają kulturowymi fikcjami - służyły regulacji stosunków sił w literaturze. Truizmem jest stwierdzenie, że grając kartą Majakowskiego, różne grupy - a było ich znacznie więcej, niż wnioskować by można tylko na podstawie stanowisk politycznych - usiłowały ubić własne interesy. Paru słów komentarza wymaga natomiast krytyka ze strony marksizujących, komunistycznych ideologów, przedstawicieli partii i organizacji robotniczych. W znacznej mierze powtarzali oni zarzuty stawiane Majakowskiemu już wcześniej, gdy owiane legendą skandalu występy jego i innych futurystów wymierzać miały policzek gustom publiczności ${ }^{6}$ i budziły zgorszenie mieszczańskich skądinąd salonów. Piętnowano więc „niezrozumiałość”, zepsucie, krzykliwość, prostactwo, antypsychologizm itd., mimo że ogromna popularność poety dowodziła jego przystępności przynajmniej dla części warstw robotniczych. Paradoksalnie jednak,

5 „Wyjaśniłem mu, kim jestem, powiedziałem, że piszę i recytuję wiersze, i wyznałem, że jego wiersze ogromnie mi się podobają. Zdziwiłem się bardzo, gdy zapytał mnie nie o to, «jak» piszę, ale «o czym piszę». Nie wiedziałem, co mam odpowiedzieć. Jak to «o czym»? O wszystkim najważniejszym. A co uważam za najważniejsze? Rzecz jasna: przyrodę, uczucia, świat! «To znaczy, że pan pisze o ptaszkach i zajączkach?»” (Asiejew, 1966, s. 288).

6 Nawiązuję do tytułu manifestu futurystów podpisanego przez Dawida Burluka, Aleksieja Kruczonycha, Władimira Majakowskiego i Welimira Chlebnikowa Policzek gustom publiczności (Burluk, Chlebnikow, Kruczonych, \& Majakowski, 1965). 
im bardziej Majakowski dbał o zrozumiałość swoich utworów i każdym słowem wspierał ideę komunizmu, tym częściej bolszewicy rugowali go z czasopism i wydawnictw i tym chętniej powielali przekonanie o przykrym zaniku indywidualizmu, rzekomo kluczowego dla twórczości tego poety, w najbardziej zaangażowanych politycznie dziełach. „Liryczna konstytucja" Majakowskiego była dla członków Rosyjskiej Asocjacji Pisarzy Proletariackich (RAPP) trudna do zniesienia - wystarczy wspomnieć ich oburzenie publikacją Listu z Paryża do towarzysza Kostrowa o istocie miłości. Niemniej jeszcze gorsze było „nieautentyczne" zaangażowanie polityczne poety, któremu wypominano nierobotnicze pochodzenie społeczne.

Nieco na marginesie dodam, że estetyka geniuszu udzielała się także najbliższemu otoczeniu poety, przebijając się nawet na poziomie słownictwa przez konstruktywistyczny żargon oraz marksistowskie i formalistyczne idee. Nikołaj Asiejew charakteryzował najbliższych współpracowników i ideowych sprzymierzeńców Majakowskiego jako tych, „którzy z miejsca odczuli pełnię jego geniuszu” (Asiejew, 1966, s. 305). Nieco dalej porównywał Majakowskiego do „oceanu wśród mórz”, wyróżniającego się „swoim kolosalnym talentem" (Asiejew, 1966, s. 322). Bolszewicki komisarz ludowy oświaty Łunaczarski miał, wedle wspomnień swojej żony Natalii Łunaczarskiej-Rozenel, zwracać szczególną uwagę na oczy poety, które „może mieć tylko człowiek utalentowany, wybitnie utalentowany” (Łunaczarska-Rozenel, 1966, s. 355). We wspomnieniach Lidii Sejfulliny „talent” Majakowskiego urasta wręcz do rangi tajemniczej energii, hipnotyzującej całą widownię, gdy tylko poeta stawał na scenie: „Czuło się, że pojawił się człowiek nieprzeciętny, ktoś, kim się wszyscy interesują i kogo wszyscy cenią". Wszyscy utkwili wzrok w twarzy pisarza, która, jak się okazuje, była „pełna woli, po męsku piękna, mądra, natchniona”. Wydobywać się z tej fizjonomii miała „owa siła, która rzadko się uzewnętrznia - niezaprzeczalna siła talentu, jego ducha” (Sejfullina, 1966, s. 382). Jeśli w oficjalnych wspomnieniach takimi słowami opisują Majakowskiego jego przyjaciele i znajomi, trudno od przeciwników oczekiwać zerwania - z jak widać przemożną - estetyką geniuszu. Nie znaczy to jednak, że stanowi ona jedyne uzasadnienie krytyki towarzyszącej działalności bohatera mojego tekstu.

Majakowskiego próbowano zepchnąć na bocznicę przeznaczoną dla tak zwanych poputczyków, literatów politycznie umiarkowanych bądź niezdecydowanych; poeci zaangażowani najwyraźniej nie byli partii potrzebni, w każdym razie od czasu względnego ustabilizowania się sytuacji w Rosji po latach konfliktów zewnętrznych i wojny domowej. Osoby i grupy posiadające własną wizję komunistycznej kultury lub komunizmu, czy też rewolucji w ogóle, a do tego wyposażone w umiejętności wyrażania tych wizji w sposób sugestywny i przekonywający stanowić mogły dla partii konsolidującej władzę w swoich rękach konkurencję. Dlatego, gdy zagrożenia militarne i ekonomiczne chwilowo osłabły, bolszewicy energicznie zabrali się za podporządkowywanie sobie sfer kultury i nauki, z rugowaniem faktycznych bądź potencjalnych sił konkurencyjnych włącznie. W pierwszej kolejności dotknęło to lewicowo zorientowaną awangardę, niemniej wraz z umacnianiem 
się rządów partii w obszarze kultury osłabieniu i instrumentalizacji uległ także masowy ruch Proletkultu. W rezolucji $O$ polityce partii w zakresie literatury z lipca 1925 roku lefowców zupełnie pominięto, proletkultowców doceniono, ale i skrytykowano, natomiast wyraźnie podkreślono rolę twórczości pisarzy pozostających raczej poza ideologicznymi i estetycznymi sporami - poputczyków (Jangfeldt, 2010, s. 295). W tym samym roku przestał się ukazywać „LEF” (wydano siedem numerów).

W drugiej połowie lat dwudziestych programem lefowców stał się produktywizm, zgodnie z którym główne znaczenie dla społecznej roli sztuki miały zamówienia publiczne - artyści mieli przede wszystkim spełniać wyrażone w nich zapotrzebowania. Pomimo podporządkowania się zamówieniom publicznym głos produktywistów nie zdołał przebić się przez rosnącą niechęć partii. Kolektyw rozpadł się w 1928 roku porzucony przez samego Majakowskiego. Założony przez poetę wraz z większością dawnych lefowców Rewolucyjny Front Sztuki (REF) miał jeszcze bardziej radykalny produktywistyczny i propagandowy program: nadrzędny był agitacyjny cel utworu, a nie, jak wcześniej, artystyczna forma. Choć REF deklarował posłuszeństwo wobec partii i tworzenie sztuki tendencyjnej, propagującej system radziecki i skierowanej do klasy robotniczej, nie miał już żadnego znaczenia (Jangfeldt, 2010, s. 420), a buntowniczą postawę lidera grupy, Majakowskiego, w encyklopedii radzieckiej ze stycznia 1930 roku określono jako „anarchistyczną i indywidualistyczną, w istocie [...] drobnomieszczańską" i daleką od światopoglądu proletariackiego (Jangfeldt, 2010, s. 460). Otwarta na początku 1930 roku wystawa Majakowskiego Dwadzieścia lat pracy została zignorowana przez wszystkich przedstawicieli władzy i świata literackiego. Ostatnie publiczne spotkanie z Majakowskim odbyło się w atmosferze nagonki, z kpiącymi okrzykami pijanych - wedle stenogramu - osób i powtarzaniem zarzutu „niezrozumiałości” w oparciu o nieistniejące wiersze lub wyrwane z kontekstu fragmenty. Wrogość radzieckich oficjeli wobec Majakowskiego w ostatnich miesiącach jego życia przybrała całkiem jawną formę. Zapamiętał ją reżyser teatralny Wsiewołod Meyerhold, którego także atakowano za współpracę z poetą:

„Z zarzutami tymi spotykałem się, poczynając od roku 1920, gdy «ośmieliłem się» wystawić jego sztukę Misterium-buffo. Pamiętam, że mnóstwo ludzi teatru mówiło wówczas, że sztuka jest «nieźle zrobiona, inscenizacja jest ciekawa», że owszem, przedstawienie ma «ostry wydźwięk», ale że «to jednak nie jest dramaturgia». Twierdzono, że Majakowski nie ma powołania na dramaturga. W roku 1928 wystawiliśmy Pluskwę i znów usłyszeliśmy niemal te same słowa. Ale ze szczególną furią atakowano nas w roku 1930, niemal w przeddzień śmierci poety, gdy wystawiliśmy Łaźnię" (Meyerhold, 1966, s. 220).

„Ja” Majakowskiego - człowieka, którego samo nazwisko wydawało się wymierzoną w system społeczny prowokacją (маяк to po rosyjsku dosłownie latarnia morska, a więc obiekt wskazujący i oświetlający drogę statkom na morzu) - wyrywające się spod kontroli, nieustannie hiperbolizowane i uwznioślane, złączone znakiem równości z przyszłością i rewolucją, nie mogło być pewnym punktem w układzie władzy. Podobnie nie była pewnym punktem rewolucyjna poezja autora 150000 000. Tomasz Tyczyński pisał, że: 
„W komunizmie realizowanym - jak w każdej utopii realizowanej - wszystko, co wymyka się spod kontroli, jest niebezpieczne. Prawdziwa sztuka zaś jest niebezpieczna szczególnie: nie dając się do końca zracjonalizować i podporządkować ideologicznej nierzeczywistości, może się okazać bardziej od niej rzeczywista, a przez to demaskatorska i niszczycielska. Dlatego właśnie staje się zbędna. I Majakowski to w końcu zrozumiał" (Tyczyński, 1995, s. 80).

\section{Sublokator we wspólnym domu}

Na temat stosunku Majakowskiego do rewolucji Jangfeldt twierdzi, że poeta „miał romantyczny i oderwany od rzeczywistości ogląd świata", zaś jego wiara w rewolucję była „naiwna” (Jangfeldt, 2010, s. 101). Autorzy współcześnie analizujący upolitycznienie twórczości i życia Majakowskiego, rosnące znaczenie komunistycznej samoidentyfikacji dla jego tożsamości oraz narastającą niechęć sfer partyjnych dochodzą nieraz do konkluzji, że Majakowski - targany kolejnymi nieszczęśliwymi miłościami i złakniony uznania dla własnego „geniuszu” - zagubił się w burzliwej radzieckiej rzeczywistości pierwszej porewolucyjnej dekady ze stratą dla swojego „talentu”, swojej kondycji psychicznej, a wreszcie swojego życia (gdy to zagubienie „w końcu zrozumiał”). Konkluzja ta zbyt często zdaje się stanowić nieuświadomioną presupozycję całego wywodu i moralne usprawiedliwienie dokonywanych przez twórcę wyborów ideologicznych. Dostrzegając ją i rozpoznając niewypowiedziane explicite stawki w grze dotychczasowych wariantów interpretacyjnych, a zatem problematyzując wcześniejsze problematyzacje ${ }^{7}$, można jednak dojść do wniosku, że Majakowski nigdzie się nie zagubit. Nie znaczy to, że w jego postępowaniu nie było wątpliwości, nagłych zmian, sprzeczności; znaczy to, że wynikały one raczej z rozwijającej się świadomości rozlicznych, skomplikowanych i chwiejnych uwarunkowań własnej sytuacji. Natomiast jego figura była na rozmaite sposoby rozgrywana i to niemal od chwili śmierci pisarza, gdy - wobec oczywistego kłopotu, jakim była samobójcza śmierć „barda rewolucji” w państwie radzieckim - Stalin jednoznacznie włączył Majakowskiego do nowego kanonu socjalistycznej literatury.

W Polsce batalia o Majakowskiego rozpoczęła się w 1950 roku artykułem Wiktora Woroszylskiego pod takim właśnie tytułem (Woroszylski, 1950, ss. 6-7). Bynajmniej nie chodziło w niej o gruntowne zgłębienie dorobku poety; jego zredukowana do wymiaru politycznego i spetryfikowana figura posłużyć miała ówczesnej krytyce literackiej do rozwiązania drażliwej kwestii awangardowych źródeł i konstytutywnych elementów obowiązującej wówczas poetyki socrealistycznej. Ściśle rzecz ujmując, pozwalała stanowczo odciąć się od - z wielu względów kłopotliwego - dziedzictwa polskiej przedwojennej, lewicowej awangardy, zaś w jej miejsce podstawić politycznie słuszny, a formalnie

7 „Jakaż ironia wysiłków, które miały na celu zmienić sposób widzenia, zmodyfikować horyzont tego, co wiadome i zapewnić spojrzenie z dystansu. [...] Czy rzeczywiście doprowadziły do myślenia inaczej? Być może pozwoliły co najwyżej myśleć inaczej o tym, co już się myślało, i spojrzeć na przebytą drogę pod innym kątem i w jaśniejszym świetle. Człowiek sądził, że się oddala, a oto stoi na wprost siebie. Podczas wędrówki młodnieją rzeczy, starzeje się zaś stosunek do siebie. Myślę, że lepiej teraz rozumiem, w jaki sposób, trochę po omacku, przez różne i kolejne fragmenty, zostałem wciągnięty w przygodę z historia prawdy: dzięki analizie nie zachowań i nie idei, nie społeczeństw i nie ich «ideologii», lecz problematyzacji, poprzez które byt dany jest jako coś, co może i musi być myślane, oraz praktyk, dzięki którym problematyzacje owe się tworzą" (Foucault, 1995, s. 151; rozstrzelenie X.S.). 
bezpieczny, rosyjski wzorzec nowoczesnego pisarstwa. Według Małgorzaty Szumnej uklasycznianie Majakowskiego przez Woroszylskiego i innych tak zwanych pryszczatych czyniło z rosyjskiego twórcy swego rodzaju atrapę, przykrojony do sztywnych wymogów socrealizmu pozór awangardy, wyprany z wszelkiej innowacyjności. Szumna, poddawszy analizie wypowiedzi uczestników tamtej dyskusji, konkludowała:

„Ostatecznym jednak dowodem na proces smętnej socrealistycznej kanonizacji Majakowskiego było umocowanie go w roli autorytetu, do którego odwoływano się, chcąc w ten sposób zabezpieczyć własne racje" (Szumna, 2011, s. 43).

Późniejsze teksty polskich autorów na temat Majakowskiego stanowiły często rewizję wypreparowanego wizerunku twórcy, co może po części tłumaczyć, dlaczego prezentowały go jako osobę targaną sprzecznymi pragnieniami, zagubioną lub naiwną. Krytyka zinstrumentalizowanego, fałszywego obrazu była niezbędna, co nie znaczy, że była absolutnie wolna od nakładania własnych, pozornie obiektywnych, a etycznych w sensie antropologicznym, kategorii poznawczych na emiczne kategorie uczestników badanej rzeczywistości. Joanna Tokarska-Bakir zwracała uwagę, że:

„Poglądy autora zawsze jednak rzucają cień na źródło. Tę przenośnię trzeba potraktować dosłownie, nie istnieje bowiem czytelnik nigdzie nieumiejscowiony. Wyjściem z sytuacji jest niekończący się proces uświadamiania sobie partykularyzmu własnego stanowiska i prób jego obrony przed zarzutem bezkrytyczności" (Tokarska-Bakir, 2012, s. 16).

Na tym kończę dygresję na temat pośmiertnej recepcji Majakowskiego. Obecne w niej wrażenie zagubienia, mówiąc wiele o badaczach życia i twórczości Majakowskiego, odnosi się przecież do rzeczywistości samego Majakowskiego: to ona jest tutaj materiałem, który ulega przemieszczeniu, odgięciu, zniekształceniu, podobnie jak w barthes'owskiej wykładni mitu [,Relacja łącząca pojęcie mitu z sensem jest ze swej istoty relacją znieksztatcania" (Barthes, 2008, s. 253; kursywa X.S.)]. Zagubienie, zbłądzenie, zauroczenie, oczarowanie (w przypadkach skrajnych: zatrucie, zaczadzenie) jest zresztą częstym motywem w schemacie narracyjnym opowieści o pisarzach, filozofach i innych intelektualistach „uwikłanych” (co stanowi tutaj jeszcze jeden synonim zagubienia czy zauroczenia) w komunizm.

Przedmiotem zniekształcenia w opowieści o zagubieniu Majakowskiego jest więc samo życie (bios) poety. O ile trudno nie zgodzić się z wcześniejszymi interpretatorami, że w żadnej z dwóch podstawowych dla niego dziedzin aktywności: literaturze i polityce Majakowski nie był u siebie, o tyle warto postawić hipotezę, według której twórca zdawał sobie sprawę ze swojego bycia nie na miejscu, nawet jeśli próbował nie dopuszczać do siebie takiej myśli. Związki Majakowskiego z obiema dziedzinami sięgają jego wczesnej młodości i od początku zaangażowanie polityczne przeplata się z praktyką artystyczną. Podczas rewolucji 1905 roku dwunastoletni Majakowski, podobnie jak inni uczniowie gimnazjum w Kutaisi (w Gruzji), brał udział w strajku gimnazjalnym, chodził na wiece, słuchał przemówień i śpiewał rewolucyjne pieśni. Starsza siostra Ludmiła dawała mu do czytania polityczne pisma i broszury. Cytuję relację matki poety, Aleksandry Majakowskiej:

SLH 2/2013 | str. 340 
„Wołodia wraz z kolegami gimnazjalnymi śpiewał po gruzińsku Warszawiankę, Śmiało, towarzysze i inne pieśni rewolucyjne.

Wiosną 1905 roku na brzegu burzliwego Rionu odbywały się wiece nastrojonych rewolucyjnie uczniów i żołnierzy. Wygłaszano tam gorące mowy. Wołodia bywał na tych wiecach.

Z początkiem czerwca 1905 roku przyjechała z Moskwy na wakacje Ludka i wszyscy wyjechaliśmy na lato do Bagdadi.

Ludka przywiozła literaturę polityczną, legalną i nielegalną, i dawała ją do czytania Wołodii, bo stwierdziła, że bardzo wydoroślał i interesuje się zagadnieniami politycznymi. Miał wtedy dwanaście lat" (Majakowska, 1966, s. 25).

Po nagłej śmierci ojca i przeprowadzce całej rodziny w 1906 roku do Moskwy Majakowski, wówczas uczeń gimnazjum klasycznego i kursów rysunku, zapoznał się z na ogół starszymi o kilka lat socjalistami - studentami podnajmującymi pokój w mieszkaniu [„Wołodia spędzał cały wolny czas z tą rewolucyjną młodzieżą" - wspominała matka (Majakowska, 1966, s. 36)] i na skutek dyskusji z nimi w 1908 roku dołączył w gimnazjum do kółka Rosyjskiej Socjaldemokratycznej Partii Robotniczej (bolszewików). Lata 1908-1909 to rosnące zaangażowanie w działalność polityczną: lektury, kolportaż, przekazywanie nielegalnych publikacji, propaganda w kręgach robotniczych, kolejne aresztowania.

Równolegle Majakowski zapoznawał się ze sztuką i literaturą (trzeba zaznaczyć, że wśród jego lektur, oprócz pism społecznych i politycznych, znalazło się sporo pieśni rewolucyjnych, wierszy, opowiadań) oraz ćwiczył się w pracach plastycznych. Usuwany ze szkół, w aresztach uczył się rysunku i nadrabiał zaległości czytelnicze, pochłaniając dosłownie wszystko: od algebry, gramatyki łacińskiej i niemieckiej, fizyki i psychologii, poprzez podręczniki historii literatury, historii sztuki i filozofii aż po literaturę piękną: Ibsena, Tołstoja, Dostojewskiego. Osadzony w więzieniu w wieku szesnastu lat zaczął pisać wiersze. Po wyjściu na wolność Majakowski musiał wybierać między sztuką a polityką i zdecydował się na tę pierwszą. Zaprzestawszy pracy w partii, zaczął uczyć się w prywatnych pracowniach malarskich, a w 1911 roku zdał do Szkoły Malarstwa, Rzeźby i Architektury. „Tak zwany dylemat” według autobiografii, czyli wybór między nauką w szkole artystycznej a oddaniem się pracy partyjnej, był dylematem bardzo prawdziwym, a motywacją pójścia do szkoły nie była bynajmniej chęć lepszej, bardziej świadomej i przemyślanej pracy propagandowej (Majakowski, 1927, ss. 32-33). Sztuka zawsze oznaczała prestiż, w szczególności w początkach XX wieku, gdy zostanie artystą mogło przynieść awans na mieszczańskie salony (tak przynajmniej sugerował mit bohemy) $\mathrm{i}$ indywidualny skok do królestwa wolności, podczas gdy polityczna walka o zbiorowy skok do tegoż królestwa oznaczała zwykle utratę szans osobistego awansu społecznego. Wybór sztuki i rezygnacja z polityki podyktowane były nie tylko marzeniem o karierze artysty, ale przede wszystkim kosztami życia, koniecznością, ponieważ młody mężczyzna w silnie patriarchalnym społeczeństwie po śmierci ojca musiał jak najszybciej przejąć obowiązek utrzymywania matki i sióstr, nie mówiąc już o zabezpieczeniu własnej egzystencji (rodzina Majakowskiego cierpiała wtedy faktyczny głód i, aby mieli co jeść, jej członkowie podejmowali się najróżniejszych prac: od artystycznych po czysto fizyczne). 
W Szkole Malarstwa, Rzeźby i Architektury Majakowski szybko związał się z wyglądającą buntowniczo, eksperymentującą bohemą. Upodobanie cyganerii artystycznej do prowokacji i skandali było dla Majakowskiego wygodne; jego prowincjonalny brak obycia, opanowania, subtelności i dobrych manier dystynktywnych dla moskiewskiego mieszczaństwa mógł zostać zaprezentowany jako obyczajowa prowokacja cyganerii wymierzona w filisterstwo:

„Jego zamaszyste, przesadnie gwałtowne ruchy, właściwy wszystkim operowym czarnym charakterom bas i wysunięta dolna szczęka, której siły nie osłabiał nawet brak przednich zębów, przydający każdym ustom wyraz gnuśności, pogłębiały jeszcze podobieństwo dwudziestoletniego Majakowskiego do członka zbójeckiej bandy albo do anarchisty-zamachowca, takiego, jakim go sobie wyobrażały przerażone strzałem Bagrowa paniusie" (Liwszyc, 1966, ss. 47-48).

Brak zębów spowodowany próchnicą u tak młodego człowieka gdzie indziej budziłby przykrość; wśród bohemy był, podobnie jak kompulsywne palenie papierosów, akceptowany jako rodzaj wyróżniającego dziwactwa. Jak wyglądał wówczas początkujący poeta i malarz, opisał jego szkolny kolega, artysta Lew Żegin:

„Majakowski hołdował wówczas stylowi vagabond. Byronowski poeta-korsarz, zsunięty na brwi czarny kapelusz z szerokim rondem, czarna bluza (zastąpiła ją wkrótce jaskrawo-żółta), czarna muszka i w ogóle wszystko czarne - taki był strój poety w latach wytężonej pracy wewnętrznej, kiedy kształtowały się zasadnicze rysy jego indywidualności twórczej" (Żegin, 1966, s. 45).

Już w 1912 roku Majakowski i jego przyjaciele stworzyli nieformalną grupę futurystów. Od grudnia 1913 do marca 1914 roku trwało tournée grupy po miastach imperium rosyjskiego. Występy przybierały formę awangardowego kabaretu, artyści obrażali publiczność, by z finezją i uciechą ripostować na komentarze o niedorzeczności i wulgarności swojej sztuki. Na scenie pojawiali się z pomalowanymi twarzami i rzodkiewkami w dziurkach od guzików; to wtedy Majakowski zaczął występować w swojej słynnej żółtej bluzie (po rewolucji styl poety uległ znacznym zmianom: stał się oszczędny, skromny, powściągliwy). W trakcie występów bywali wygwizdywani, wyśmiewani, zaczepiani; publiczność czuła się rozczarowana, gdy zabrakło skandalu. Nie inaczej traktowała ich wiersze prasowa krytyka literacka. Oburzenie zachowaniem futurystów było tak wielkie, że wkrótce Majakowski został usunięty ze studiów - tym razem za poezję, a nie za politykę.

A zatem Majakowski wszedł w świat sztuki i polityki już jako nastolatek, i już wtedy w obu z nich przypadł mu status outsidera albo sublokatora. Anna Zawadzka nazywa „strategiami sublokatorskimi” takie zachowania, które niezależnie od stopnia ich uświadomienia i intencjonalności służą podporządkowaniu się przez „osoby o publicznej tożsamości żydowskiej” „antysemickim regułom polskiej sfery publicznej”, na przykład udowadnianie swojego patriotyzmu mimo bycia Żydem albo walka z oskarżeniami Polaków o antysemityzm podejmowana z powodu bycia Żydem. Innymi słowy, strategie sublokatorskie polegają na dopasowywaniu się mniejszości do ram i reguł skonstruowanych przez większość i na korzyść większości, a celem ich „jest ciągle to samo: prawo pobytu 
i prawomocność" (Zawadzka, 2012, s. 124). Majakowski był sublokatorem niekonwencjonalnym i skrycie bądź otwarcie wrogim dotychczasowym gospodarzom obu przestrzeni - jako rewolucjonista za caratu i futurysta, kiedy w poezji dominowali symboliści i akmeiści, domagał się prawa pobytu w sferze publicznej na własnych zasadach. Gwałtowne przemiany społeczno-kulturowe i polityczne drugiej dekady XX wieku nie przyniosły jednak autorowi Fletu kręgosłupa prawa „bycia u siebie” ani w literaturze, ani w polityce.

Dziewiętnastowieczna historiozofia rosyjska często posługiwała się motywem wspólnego domu. W różnych utopiach, niezależnie od ich filozoficznej czy ideologicznej proweniencji, domem tym dla narodów słowiańskich bądź dla całego świata miała być Rosja: kraj przyszłej wolności, sprawiedliwości, prawdy lub innych pozytywnie waloryzowanych wartości i idei. Odległe od siebie pod względem wizji przyszłych wydarzeń czy idealnego porządku społecznego różne próby futurologii lub prefiguracji przyszłości łączył fakt, że zazwyczaj zawierały one, mniej lub bardziej wyraźny, pierwiastek imperialistyczny. Przenikał on wraz z motywem wspólnego domu do utopii lewicowych. Witold Parniewski dowodził, jak bliskie były wizje zawarte w teokratycznej utopii Władimira Sołowjowa i w utopii bolszewickiej Aleksandra Bogdanowa. Bogdanow, działacz komunistyczny, bliski i wierny współpracownik Lenina, był autorem utopii Czerwonej Gwiazdy, idealnie urządzonej komunistycznej planety, której mieszkańcy „są już jednym narodem czy raczej jedną zwartą społecznością, o jednym światopoglądzie" (Parniewski, 1995, s. 150). Klasy i narody zastąpić miała ludzkość, niemniej to Rosja miała być domem ludzkości, a rosyjski proletariat miał wskazać ludzkości drogę do tego domu. Elementy utopii wspólnego domu z łatwością znaleźć można również w twórczości Majakowskiego, w której rodziną bohatera staje się niekiedy cała ludzkość, cały wszechświat. Tymczasem, gdy partia bolszewicka przejęła władzę i - napiszmy kolokwialnie - zabrała się za porządki we wspólnym domu, okazało się, że Majakowskiemu mimo jego ideowego oddania i zaangażowania wciąż przysługiwał status jedynie współlokatora, chwilami wprawdzie dość przychylnie traktowanego, a nawet cenionego, niemniej nieustannie subordynowanego, aby nie zapomniał, kto jest rzeczywistym gospodarzem.

\section{Ojczyzna jako obczyzna}

Sublokator Majakowski rozumiał swoją podległość, lecz nie mógł - albo nie chciał się na nią zgodzić. Postępował więc ambiwalentnie. Z jednej strony starał się udowodnić, że jest wzorowym obywatelem radzieckim, posłusznym nowej władzy i oddanym komunistycznym ideom, aby zyskać partyjną legitymizację swojej osoby w literaturze i polityce. Z drugiej strony uparcie powracał do własnej wizji komunizmu i nie wahał się przeciwstawiać jej bolszewickiej ortodoksji. W efekcie strategia sublokatorska od wyrazów posłuszeństwa i deklaracji poparcia przechodziła momentami w otwarty konflikt. Wyraz tej ambiwalencji, w której punkt zaczepienia znajdują narracje o ideowym pobłądzeniu Majakowskiego („romantyczny i oderwany od rzeczywistości ogląd świata”), można 
znaleźć w dwóch wierszach wykorzystujących metaforę domu. W wierszu Do domu! powstałym w 1925 roku w drodze powrotnej z Ameryki do Związku Radzieckiego emocjonalny stosunek do domu oraz temat tożsamości i wyobcowania podkreśla już sam tytuł zakończony wołaczem. Poeta podróżował do domu, ale też zwracał się do domu, czyli do swojego kraju, jego mieszkańców i władzy, a w jeszcze innym sensie: do domu jako do komunizmu, a więc do domu, który dopiero jest budowany:

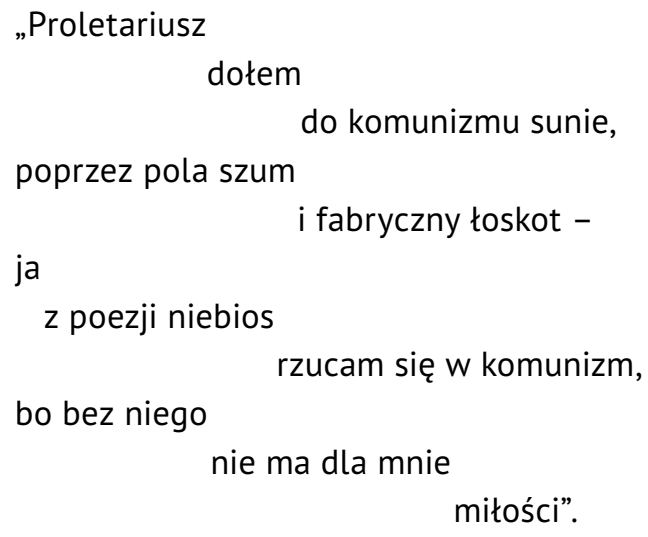

(Do domu!, cyt. za: Woroszylski, 1965, s. 536)

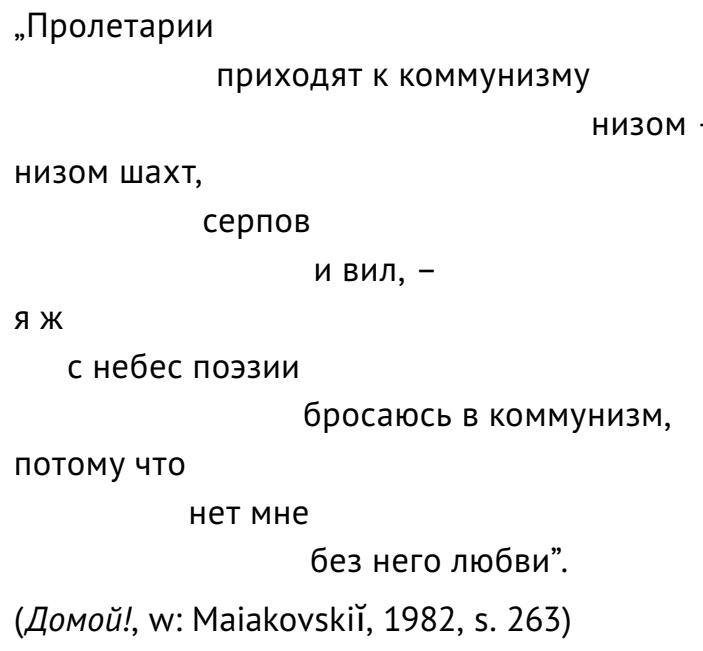

Bez komunizmu nie ma miłości, a jest ona dla autora jednoczącą i twórczą siłą, która wznieca bunt w starym świecie, kładzie podwaliny nowego świata, a wreszcie, jako niewyczerpane źródło energii witalnej, jest przyczyną, dla której Majakowski domaga się wskrzeszenia po śmierci w wierszu O tym (Majakowski, 1959, s. 220). Zbawienie w komunizmie polega na transgresyjnej miłości. Podkreśla to zestawienie z poprzedzającym cytowany fragment wątkiem płatnego seksu na Zachodzie. Jednakże twórca nie przekonywał o realności takiej zbawczej miłości w radzieckiej Rosji - nakładał na rzeczywistość swoją projekcję stanu idealnego, swoje marzenie o komunizmie. Tylko to wyjaśnia ekstatyczny akt rzucenia się „z poezji niebios” w komunizm, w dół, którym „sunie, przez pola szum / i fabryczny łoskot" (dosłownie: z dołu kopalń, sierpów i wideł) proletariusz. 
Dalej poeta porównuje się do maszyny, „mechanizmu”: „Ja się czuję/ fabryką radziecką,/ wyrabiającą szczęście” (Do domu!, cyt. za: Woroszylski, 1965, ss. 536-537) [„Я себя/ советским чувствую/ заводом,/ вырабатывающим счастье" (Домой!, w: Maiakovskil̆, 1982, s. 264)]. Jako „fabryka” (завод) domaga się więc „planów”, „zadań” (задания, с приказанием) i „zapotrzebowania” od „komisji państwowej” (Госплан), „by według rozdzielników dla speca/ wydawano/ miłość/ dla serca” („Я хочу,/ чтоб сверхставками спеца/ получало/ любовищу сердце”). O ile pierwsza część tego fragmentu odpowiada postulatom produktywizmu, kierunku, który Majakowski wówczas reprezentował, o tyle żądanie reglamentacji miłości daleko wykracza poza te postulaty dotyczące głównie społecznych i politycznych funkcji sztuki - jest to przecież wołanie o sens egzystencji, tak potrzebny fabryce „wyrabiającej szczęście”, że podmiot deklaruje dalej:

"Chcę,

by po pracy dyrektor zakładu

na me wargi kłódkę zakładał.

Chcę,

by z bagnetami zrównano pióra.

Wraz z żeliwem

i produkcją stali

o robieniu wierszy

w imieniu Politbiura

by referat

wygłaszał

Stalin".

(Do domu!, cyt. za: Woroszylski, 1965, s. 537)

„Я хочу

чтоб в конце работы

завком

запирал мои губы

замком.

Я хочу,

чтоб к штыку

приравняли перо.

С чугуном чтоб

и с выделкой стали

о работе стихов,

от Политбюро,

чтобы делал

доклады Сталин".

(Домой!, w: Maiakovskil̆, 1982, ss. 264-265)

Deklaracja całkowitego posłuszeństwa i uległości twórcy wobec partii reprezentowanej przez Stalina (Majakowski nie darzył go specjalną sympatią, wybór jego nazwiska podyktowany został rymem) nie wynikała z pragmatyzmu czy serwilizmu - chodziło 
właśnie o miłość, która nie istnieje bez komunizmu. Jeśli więc komunizm radziecki jako warunek miłości wymaga ścisłego podporządkowania poezji zamówieniom państwowym, należy się temu bezwzględnie podporządkować. Poeta miał przy tym świadomość, że w swoich rachubach może się pomylić, a nawet, że prawdopodobieństwo takiej pomyłki jest znaczne. Dawał temu wyraz w ostatniej zwrotce wiersza, w której pisał o pragnieniu bycia zrozumianym w ojczyźnie, ale godził się też z brakiem zrozumienia („nie pojmie - zniosę to też”). W takiej sytuacji miałby przejść nad swoim krajem „bokiem”, „jak ukośny/ przechodzi/ deszcz" (Do domu!, cyt. za: Woroszylski, 1965, s. 538) (w wydaniu rosyjskim brak tej zwrotki). Porównanie siebie do deszczu w ostatnim wersie utworu to odejście od stylistyki produktywizmu („mechanizm”, „fabryka”) ku bardziej pierwotnej, archaicznej symbolice przyrodniczej, w której deszcz posiada konotacje płodności, witalności, a nieobecne są sfery mechaniki i produkcji; twórczość powraca i zastępuje wytwarzanie. Skok z „poezji niebios” w komunizm okazuje się ostatecznie przechodzącym „bokiem” nad ojczyzną, spadającym z nieba deszczem, który zapładnia, odradza, ożywia ziemię komunizmu, we wcześniejszych wierszach rewolucyjnych metaforyzowanego jako flagi umożliwiające ludowi wdarcie się do nieba. Sama zaś ojczyzna jest jednocześnie obczyzną - z zachowanego brudnopisu wynika, że autor wahał się między tymi dwoma słowami (Jangfeldt, 2010, s. 321). Majakowski-sublokator nie mógł zdecydować się, czy jego dom to ojczyzna, czy obczyzna.

Z wierszem Do domu! pod wieloma względami symetryczny jest utwór Do Rosji, napisany jesienią 1917 roku, a więc bezpośrednio po przejęciu władzy przez bolszewików (prawdopodobnie ze względów bezpieczeństwa datowany na rok 1916). Utwór ten swoją pesymistyczną wymową kontrastował z erupcją entuzjastycznej twórczości Majakowskiego po rewolucji lutowej. Podmiot w wierszu Do Rosji jest jednostkowy i osamotniony: „niby struś-dziwo” (заморский страус), mieniący się „strof i rymów piórami” (в перьях строф, размеров и рифм) idzie przez obcy, niechętny mu kraj, do którego krzyczy: „Nie twój jestem, śniegowy koszmarze” (Majakowski, 1967, s. 40) [„Я не твой, снеговая уродина” (Poccuu, w: Maiakovskil̆, 1982, s. 94)]. Choć błędem byłoby redukowanie znaczenia tych słów do bieżącego komentarza politycznego, to wypowiedzenie ich do radzieckiej już wówczas Rosji uważam za wyraz niezgody na ówczesne wydarzenia polityczne, a nie tylko kolejną wariację na temat alienacji poety z mieszczańskiego otoczenia społecznego, co znamy z wcześniejszych poezji Majakowskiego. Poeta, „struś-dziwo”, kroczy więc w poszukiwaniu innej ojczyzny, w „wypalone/ dni południowe” (выжжена южная жизнь), со można rozumieć jako powrót strusia do jego kraju pochodzenia - Afryki, a metaforycznie - jako wskazanie przez Majakowskiego miejsca, w którym się urodził, czyli wioski Bagdadi w Gruzji, na ciepłych południowych krańcach rosyjskiego imperium. Jednak wędrówka na południe okazuje się ciągiem nieporozumień, które „fantazję łamią” (Выдумку мнут), a napotykane postacie reagują na bohatera lękiem lub pustymi pochlebstwami. Poszukiwanie własnego miejsca kończy się fiaskiem, a bohater, który - wnioskując z "chłodów fali" (Обдают водой холода) - znów odnajduje się w Rosji, z goryczą przyznaje: 
„Ja, obmacany dymami i palcami,

przez lata się przelewam".

„Весь истыканный в дымы и в пальцы,

переваливаю года".

I znów zwraca się w gorzkich słowach bezpośrednio do Rosji:

„No cóż, zwal mnie obmierzłym chwytem.

Brzytwą wiatru ogol mi pióra.

Niech sczeznę,

dziwo niesamowite,

w rozpasanych grudni wichurach".

(Do Rosji, w: Majakowski, 1967, s. 41)

„Что ж, бери меня хваткой мёрзкой!

Бритвой ветра перья обрей.

Пусть исчезну,

чужой и заморский,

под неистовства всех декабрей".

(Poccuu, w: Maiakovskiĭ, 1982, s. 95)

Rosję Radziecką poeta zaakceptował dopiero rok później, gdy wstąpił do utworzonego przez bolszewików Wydziału Sztuk Plastycznych (IZO) i zaczął opowiadać się za podejmowaniem tematów politycznych w literaturze. Wcześniej, w marcu 1917 roku, na fali karnawałowej atmosfery wolności po rewolucji lutowej Majakowski nawoływał: „niech żyje życie polityczne Rosji i niech żyje wolna od polityki sztuka!"8. W trakcie łączącego przeciwieństwa i jednoczącego społeczeństwo święta rewolucji te dwa hasła nie kłóciły się ze sobą. Szczególnie dla artystów i literatów zmiana polityczna zdawała się oznaczać przede wszystkim koniec cenzury, a więc wreszcie możliwość tworzenia nieskrępowanego politycznymi decyzjami. Uzyskanej dzięki rewolucji autonomii sztuki bronić miał powstały już w marcu 1917 roku Związek Pracowników Kultury, w skład którego wchodzili twórcy wszystkich kierunków artystycznych i opcji politycznych. Majakowski był reprezentantem pisarzy w prezydium Związku i podobnie jak inni uważał, że sztuka powinna być jak najbardziej niezależna od decyzji politycznych (co nie znaczy, że sama nie powinna podejmować kwestii politycznych). Choć polityczny ferment jest generalnie zjawiskiem pozytywnym, powinny zostać jasno wyznaczone granice, aby władza polityczna nie ingerowała w sferę sztuki poza społeczną kontrolą i wyznaczonymi regułami.

Jesienią 1918 roku decyzja o wstąpieniu do kierowanego przez bolszewików IZO wydawać się mogła jedynym możliwym posunięciem. Dłużej bronić niezależności sztuki już się nie dało, awangarda zadeklarowała się zatem jako siła rewolucyjna, przyjazna nowej władzy, by zdobyć jej akceptację i pod jej egidą odzyskać wpływ na politykę kulturalną. Pół roku wcześniej policja polityczna wyeliminowała z polityki anarchistów, a następnie

8 Ze stenogramu wiecu w Teatrze Michajłowskim, oprac. Jefim Dinersztejn (Puścizna literacka, t. 65: Nowe o Majakowskim, Moskwa 1958, cyt. za: Woroszylski, 1965, s. 239). 
wezwała ludzi kultury i nauki, by określili się pod względem politycznym. Majakowski stanął wówczas po stronie bolszewików, niemniej przed listopadem 1917 roku oraz w ciągu następnych miesięcy skłaniał się raczej ku anarchokomunizmowi; miał nawet pomysł, by w wyborach parlamentarnych wystawić własną listę wyborczą futurystów (Asiejew, 1966, s. 317). Gdy bolszewicy przejęli rządy drogą przewrotu politycznego, powiedział chłodno: „Wypada powitać nową władzę i nawiązać z nią współpracę” (Jangfeldt, 2010, s. 103) ${ }^{9}$. Wciąż jednak była to władza w ojczyźnie-obczyźnie. Nie mylił się Nikołaj Asiejew, twierdząc, że rzeczywistą ojczyzną Majakowskiego była rewolucja (Asiejew, 1966, s. 281).

\section{„Rewolucja Ducha”}

Jakkolwiek Majakowski wierzył w zgoła odmienną rewolucję niż forsowane przez partię zmiany, wobec kurczenia się pola manewru nie widział innego wyjścia niż stanąć po stronie władzy, oczekując z jej strony zaufania. Bolszewicy mimo wszystko byli depozytariuszami komunistycznej utopii, w którą on mocno wierzył, i ta wiara mogła mieć niebagatelny wpływ na podporządkowanie się twórcy dyktaturze kosztem krótszego lub dłuższego tłumienia własnych dążeń. Majakowski pozostawał zawsze zwolennikiem rewolucji, a nie stabilizacji ustroju radzieckiego. Chcę w tym miejscu nieco bliżej przyjrzeć się wizji tej rewolucji, która miała być totalna, miała objąć nie tylko sfery instytucjonalnej polityki, stosunków produkcji czy struktury społecznej, lecz także sztukę, moralność, filozofię, przyrodę, a nawet prawa fizyczne. Dlatego Majakowski nazwał ją „Rewolucją Ducha”, pisząc w Liście otwartym do robotników jesienią 1917 roku z typowo religijną metaforyką:

„Towarzysze!

Podwójny pożar wojny i rewolucji opustoszył nasze dusze i nasze miasta.

Jak wypalone szkielety stoją pałace wczorajszego przepychu. Rozgromione miasta czekają na nowych budowniczych. Huragan rewolucji wykarczował z dusz koślawe korzenie niewolnictwa. Dusza ludu oczekuje wielkiego siewu.

Do was, którzy przyjęliście puściznę Rosji, do was, którzy (wierzę!) jutro staniecie się panami całego świata, kieruję pytanie: jakimi fantastycznymi gmachami pokryjecie miejsce wczorajszych pożarów? Jakie pieśni i muzyki poleją się z waszych okien? Jakim bibliom otworzycie swe dusze?

\section{$[\ldots]$}

Wiedzcie, że dla naszych szyj, szyj Goliatów pracy, nie ma odpowiednich numerów w garderobie kołnierzyków burżuazji. Jedynie wybuch Rewolucji Ducha oczyści nas od łachów starej sztuki.

Rewolucja treści - socjalizm-anarchizm - jest nie do pomyślenia bez rewolucji formy - futuryzmu.

Chciwie rwijcie kęsy zdrowej młodej brutalnej sztuki, jakie wam dajemy.

9 Prawdopodobnie to ta sama wypowiedź, która w książce Woroszylskiego brzmi: „trzeba zwrócić się do władzy, powitać nową władzę” („Z protokołu nadzwyczajnego posiedzenia Komitetu Tymczasowego Związku Działaczy Sztuki, 17 listopada 1917”, cyt. za: Woroszylski, 1965, ss. 253-254). 
Nikt nie może wiedzieć, jakimi ogromnymi słońcami będzie oświetlone przyszłe życie. Może artyści w stubarwne tęcze przeistoczą szary kurz miast, może z łańcuchów górskich będzie rozbrzmiewała nie milknąca gromowa muzyka zamienionych we flety wulkanów, może fale oceanów zmusimy do przebierania sieci przeciągniętych z Europy do Ameryki strun. Jedno jest dla nas jasne - otworzyliśmy pierwszą stronicę najnowszej historii sztuki” (cyt. za: Woroszylski, 1965, ss. 260-261).

Ten entuzjastyczny, pełen patosu apel, wystosowany do robotników na łamach „Gazety Futurystów" (jedyny numer tego pisma składał się z wierszy, artykułów i manifestów, a zamiast tradycyjnego kolportażu rozklejany był na moskiewskich ulicach) i akcentujący przede wszystkim etyczny i estetyczny, a nie społeczno-ekonomiczny wymiar rzeczywistości, zawiera najważniejsze myśli Majakowskiego: konieczność powiązania nowych form społecznych z nowymi formami artystycznymi oraz nadejścia trzeciej rewolucji po rewolucjach 1905 i 1917 roku - rewolucji „duchowej”, obejmującej całą kulturę (w sensie antropologicznym), przede wszystkim zaś strukturę świadomości, pole percepcji, sposób doświadczania rzeczywistości i metody rozumowania. Myśli te sformułowano z pełną powagą; futuryści zgłaszali gotowość bezpłatnych wystąpień przed robotniczą publicznością i oczekiwali propozycji. Poeta Siergiej Spasski relacjonował:

„Futuryści czekają na zaproszenia. Posłowie jednak nie przybywają znikąd. Budzi to zdumienie. Na razie - brak uznania.

«Dziwimy się, że dotychczas cała prasa demokratyczna całkowicie ignoruje nasze rewolucyjne poczynania».

Widocznie trzeba samym pójść do mas. Rozwijać się razem z proletariatem" (Spasski, 1966, s. 120).

Mimo początkowego niepowodzenia Majakowski był wierny przekonaniu o potrzebie „Rewolucji Ducha”, wracał do niego w poematach Człowiek i 150000 000, a wreszcie w Czwartej Międzynarodówce z 1920 roku. Czwarta Międzynarodówka stanowiła atak na zachowawczą politykę kulturalną bolszewików, przypuszczony w obronie idei „Października”. Zarzucając bolszewikom „duchową pustkę” i zmierzanie „ku gorylom”, poeta wzywał do „trzeciej rewolucji”, którą miała być właśnie „Rewolucja Ducha” (Jangfeldt, 2010, ss. 164-165).

We Wstępie do Przyczynku do krytyki heglowskiej filozofii prawa Karol Marks pisał, że „być radykalnym znaczy ujmować rzecz od korzenia. Lecz dla człowieka korzeniem jest sam człowiek” (Marks, 1949, s. 24). W ten sposób Marks uzasadniał krytykę religii: „człowiek jest najwyższa istotą dla człowieka, a więc kategorycznym nakazem obalenia wszystkich stosunków, w których człowiek jest istotą poniżoną, ujarzmioną, opuszczoną i godną pogardy" (Marks, 1949, s. 24; kursywa X.S.). Dla Majakowskiego korzeniem, tym poniżanym, opuszczonym człowiekiem był przede wszystkim Chrystus; symptomatyczne, że do człowieka poeta dociera nie poprzez negację religii, lecz poprzez ponowne odczytanie historii biblijnej i utożsamienie się z jej głównym bohaterem. Dziennikarz Nikołaj Sieriebrow (właściwie: Aleksandr Tichonow) odnotował, w jaki sposób Maksim Gorki porównywat temperament i styl Majakowskiego do proroka Izajasza (Sieriebrow, 1966, s. 89). 
Na okładce poematu Człowiek z 1918 roku nazwisko autora i tytuł książki tworzą znak krzyża. Otwierający ten poemat fragment Narodziny Majakowskiego opiera się na wydobywaniu różnic między przyjściem na świat twórcy a narodzinami Chrystusa - Syna Bożego. Pisze więc Majakowski, że jego „dzień/ zstąpienia” (день моего сошествия к вам) byt „zupełnie podobny do innych” (Был абсолютно как все), „aż do nudności jednaki” (до тошноты одинаков) i nie zapowiadały go żadne znaki na niebie nad Betlejem. W ten sposób poeta odcina się od „oklasków popich” (аплодисменты попов) i podkreśla swoją ziemską, fizyczną postać, a poprzez analogię historię Jezusa odczytuje jako los ludzki (Majakowski, 1959, s. 92) ${ }^{10}$. We wczesnym wierszu A jednak z 1914 roku, wymierzonym w mieszczaństwo i jego „sąd ostateczny”, nazywa siebie prorokiem i poetą syfilityków i prostytutek, które go „poniosą niby świętość” (Majakowski, 1957, s. 34) [„как святыню, на руках понесут" (А все-таки, w: Maiakovskiї, 1982, s. 63)], aby poezją Majakowskiego usprawiedliwić się przed Bogiem. W pisanym w latach 1916-1917 poemacie Wojna i pokój (tłumaczonym też jako Wojna i świat) Majakowski podkreśla przejście od figury proroka do kozła ofiarnego, który swoim cierpieniem odkupuje grzechy świata, bierze na siebie winy i prosi o przebaczenie - w funkcji kozła ofiarnego występuje sam podmiot liryczny (Jangfeldt, 2010, s. 97). „Odkupicielem miłości błędów” (земной любви искупителем значасb) nazywa się poeta w poemacie O tym, zapewniając: „za wszystkich stać będę -/ za wszystkich zapłaczę,/ za wszystkich odpłacę” (Majakowski, 1959, s. 209) [„стою за всех,/ за всех расплачусь,/ за всех расплачусь” (Про это, w: „Vladimir Maiakovskiі̆. Biblioteka Poėzii", b.d.)].

Majakowski - zstępujący z wyżyn poezji w propagandową pracę na rzecz budowy komunistycznego społeczeństwa, rezygnujący ze szlachecko-inteligenckiego pochodzenia [„Ojciec mój,/ szlachcic wielmożny wielce,/ skórę na dłoniach mam cienką” ( 0 tym, w: Majakowski, 1959, s. 217); „Столбовой отец мой/ дворянин,/ кожа на моих руках тонка” (Про это, w: „Vladimir Maiakovskiĭ. Biblioteka Poėzii”, b.d.)] na rzecz nowej, proletariackiej tożsamości, o której społeczne potwierdzenie zabiegał przez całe życie - dokonywał swoistego powtórzenia aktu kenozy. Między odrzuceniem zastanego statusu społecznego i własnej tożsamości posuniętym aż do samobójstwa klasowego i stawiania stopy na gardle swej pieśni (Na cały głos, w: Majakowski, 1959, s. 441) a dobrowolnym przyjęciem przez Chrystusa kondycji ludzkiej, czyli między poziomem psychospołecznym a teologicznym, dostrzec można homologię.

Celem „Duchowej Rewolucji” Majakowskiego była transformacja struktury świadomości ludzkiej. Gra toczyła się o całokształt kultury: od modeli percepcji czy doświadczania rzeczywistości po hierarchie wartości, postawy i rodzaje więzi międzyludzkich, co znalazło poetyckie odzwierciedlenie w czterech głównych okrzykach poematu Obłok w spodniach: „precz z waszą miłością”, „precz z waszą sztuką”, „precz z waszym ustrojem”, „precz z waszą religią". Był to program maksymalistyczny, do którego zmiana posiadania środków własności i obalenie dawnego ustroju politycznego były tylko wstępem. Majakowski

10 Fragmenty w oryginale: Человек, суt. za: „Vladimir Maiakovskǐ̌. Biblioteka Poèzii”, b.d. 
przeczuwat, że przemiany polityczno-ekonomiczne nie wystarczą, by stworzyć nowego człowieka, o którego, podobnie jak wielu innych artystów tego czasu, usilnie walczył. A była to - w jego języku - walka z „bytem”, czyli „z rutyną codzienności i brakiem smaku", jak precyzował Jangfeldt (Jangfeldt, 2010, s. 246). Sieriebrow zauważał, że wrogów szydzących z niego w teatrach i gazetach Majakowski nazywał „burżujami”, „mieszczuchami” i „farmaceutami” (Sieriebrow, 1966, s. 90). Powraca tu, wskazywane już kilkakrotnie, etyczno-estetyczne nastawienie Majakowskiego do świata: krytyka codzienności, tłumu, mieszczucha jako przejawów panowania zasady rzeczywistości. Przeciwstawiał się Majakowski życiu wtłoczonemu w stare koleiny, wypłukanemu z energii, nakierowanemu na zaspokajanie podstawowych popędów i potrzeb fizycznych, a nie na twórcze przeżywanie i przekształcanie swojego bycia w świecie. Egzystencji nieświadomej, pasywnej, podporządkowanej konieczności Majakowski - sam przecież silnie doświadczający rozmaitych cierpień, przymusów i niepowodzeń, od śmierci ojca poprzez areszty i więzienie, głód, po rozstania z ukochanymi osobami i nieprzychylność władz dla jego pisarstwa - przeciwstawiał całkowitą wiarę „w to życie,/ w ten/ świat” (O tym, w: Majakowski, 1959, s. 219) [„в жизнь сию,/ сей/ мир” (Про это, w: „Vladimir Maiakovskil̆. Biblioteka Poèzii”, b.d.)].

Rewolucja, do której poeta miał stosunek także estetyczny, musiała jawić mu się jako zwycięstwo sił witalnych nad zmurszałymi formami i konwencjami, zwłaszcza jeśli weźmiemy pod uwagę realny wybuch społecznej euforii w marcu 1917 roku. W przekonaniu o oczyszczającej i twórczej mocy rewolucji Majakowski nie był zresztą odosobniony. Jednakże szybko zorientował się, że zmiany zaprowadzane przez bolszewików nie idą w tę stronę, w którą pragnął - najboleśniej zapewne odczut to na gruncie polityki kulturalnej, która promowała nurty klasycyzujące, umiarkowane, bezpieczne. Dlatego droga rewolucji Majakowskiego przeciwko „bytowi” i droga politycznego przewrotu bolszewików szybko się rozeszły, choć poeta niezmiennie popierał nowy ustrój i firmował swoją twórczością politykę partii.

\section{Miłość i rewolucja}

Nieco wyżej wstępnie ustaliłem związki łączące w myśli Majakowskiego miłość i komunizm; w tym miejscu chcę przyjrzeć się im dokładniej. Komunizm był dla Majakowskiego bezwzględnym warunkiem miłości, tylko dzięki niej możliwe jest zbawienie (leży ona w centrum komunistycznej soteriologii), a jednocześnie stanowi ona energię łączącą ludzi w akcie rewolucyjnym. Relacje między miłością a rewolucją są dwukierunkowe, konieczne i komplementarne. Dlatego stosunek emocjonalny Majakowskiego do rewolucji był równie silny i osobisty jak do najbliższych mu ludzi. W tej optyce mieszczański, liberalny podział na sferę publiczną i prywatną stał się złudny i alienujący.

Podobny holistyczny pogląd reprezentowały w pierwszej połowie lat dwudziestych wpływowe postacie radzieckiego życia politycznego. Aleksandra Kołłontaj, działaczka robotnicza, twórczyni Żenotdiełu - departamentu do spraw kobiet w radzieckim rządzie 
- głośno propagowała wolną miłość, także w znaczeniu prawa kobiet do swobodnego dysponowania własnym ciałem. Już w 1909 roku krytykowała ucisk i uprzedmiotowienie kobiet w rodzinie, uznając „kwestię rodziny” za równie ważną jak prawa polityczne i równość ekonomiczna. W artykule Problem małżeństwa i rodziny pisała: „By zyskać prawdziwą wolność, kobieta musi zrzucić z siebie ciężkie łańcuchy obecnych przestarzałych i opresyjnych form rodziny" (Kołłontaj, 2012, s. 108). Możliwość zrzucenia łańcuchów Kołłontaj widziała nie w sprzeciwie wobec kontraktu małżeńskiego (sprzeciw ten nazwała wręcz fetyszem feministek), lecz w przeniesieniu na społeczeństwo wychowawczych, opiekuńczych i innych funkcji, które w gospodarstwie domowym wypełniała zwykle kobieta. Poprzez zmiany na poziomie organizacji społecznej rodzina nuklearna - „produkt współczesnego indywidualistycznego świata, z jego wyścigiem szczurów, presją, samotnością", wytwór „potwornego systemu kapitalistycznego” - mogłaby wreszcie zostać zastąpiona przez „wolny związek kochających się jednostek” (Kołłontaj, 2012, s. 109). W podobnym tonie wypowiadał się w 1923 roku jeden z przywódców bolszewików, Lew Trocki, kładąc akcent na potrzebę uspołecznienia pracy domowej wykonywanej zwyczajowo przez kobiety (dzięki czemu rodzina ze spełniającej społeczne funkcje instytucji przeistoczyłaby się w opartą na wzajemnym przywiązaniu grupę) i postulując, by „zrewolucjonizować wszelkie nasze domowe zwyczaje" (Trocki, 2012, s. 110).

Miłość, małżeństwo, rodzina nie były dla przywódców bolszewickich nic nieznaczącymi tematami obyczajowymi czy prywatnymi sprawami obywateli - przeciwnie, skupiały na sobie zainteresowanie i troskę jako te elementy systemu społecznego, które mogą wesprzeć i utwierdzić osiągnięcia rewolucji bądź zakonserwować przedrewolucyjne, nierównościowe stosunki społeczne. Dlatego również w 1923 roku ludowy komisarz oświaty i bliski znajomy Majakowskiego, Łunaczarski, dowodził, że niezbędnym warunkiem budowy wolnego, komunistycznego społeczeństwa jest akceptacja wolnej miłości, a jakiekolwiek ingerencje państwa w życie seksualne i uczuciowe obywateli miałyby kontrrewolucyjny charakter. „Moralność społeczeństwa komunistycznego będzie polegała na tym, iż znikną wszelkie ograniczenia prawne - będzie to moralność całkowicie wolnych ludzi" - uważał (cyt. za: Jangfeldt, 2010, s. 329). Pod tymi słowami z pewnością mógłby podpisać się również Majakowski. Dla niego miłość, jeden z najważniejszych tematów twórczości i nieodłączna część rewolucji, rodzaj ponadludzkiego żywiołu i palącego, transgresywnego entuzjazmu, stanowiła siłę wywrotową, główny motor przemian i podstawową treść relacji międzyludzkich. To o niej poeta w tym samym roku pisat, że: „u Negra ostrzy swój nóż przeciw panom” (O tym, w: Majakowski, 1959, s. 169) [„у негра вострит на хозяев нож” (Про это, w: „Vladimir Maiakovskiĭ. Biblioteka Poėzii”, b.d.)]. W dalszej partii poematu $O$ tym, z którego pochodzi ten cytat, rewolucyjna, globalna rola miłości zostaje jeszcze bardziej uwydatniona:

„By nie było miłości-służki,

$$
\text { małżeństw, }
$$

żądzy,

codziennych potrzeb. 
Niechaj miłość

$$
\text { przekląwszy tóżka }
$$

wstanie

i na wszechświat się rozpostrze.

Aby dzień

naszych żalów nie słyszał

starzejąc się od cierpienia.

Aby cała

na krzyk:

- Towarzyszu! -

odwracała się ziemia.

Aby żyć

nie jak ofiara żłobu.

Aby mogto się

w rodzinie

stać tak:

ojciec -

przynajmniej globem,

ziemią przynajmniej - matka".

(O tym, w: Majakowski, 1957, ss. 222-223)

„Чтоб не было любви - служанки

замужеств,

похоти,

хлебов.

Постели прокляв,

встав с лежанки,

чтоб всей вселенной шла любовь.

Чтоб день,

который горем старящ,

не христарадничать, моля.

Чтоб вся

на первый крик:

$$
\text { - Товарищ! - }
$$

оборачивалась земля.

Чтоб жить

не в жертву дома дырам.

Чтоб мог

в родне

отныне

стать

отец

по крайней мере миром,

землей по крайней мере - мать".

(Про это, w: „Vladimir Maiakovskil̆. Biblioteka Poėzii”, b.d.) 
Powyższe żądanie nie było poetycką metaforą, lecz ekspresją realnych emocji. Asiejew potwierdza, że faktycznie dla Majakowskiego „rodziną byli wszyscy ludzie, których uznawał za godnych miana człowieka”, z czym dodatkowo kontrastuje umiarkowane przywiązanie do najbliższych krewnych, skoncentrowane na zabezpieczeniu materialno-finansowym: „Długich rozmów rodzinnych nie prowadził jednak. Nie lubił tego. Miał inne zainteresowania" (Asiejew, 1966, ss. 301-302). Styl życia Majakowskiego odbiegał od mieszczańskiej normy społecznej równie daleko jak poglądy.

Żądanie to bez wątpienia cechuje radykalizm w znaczeniu, jakie temu pojęciu nadał Helmuth Plessner: „unicestwienie zastanej rzeczywistości w imię idei, która może być racjonalna lub irracjonalna, ale zawsze jest nieskończona" (Plessner, 2008, s. 12). Takiej wizji charakterystycznej dla antystrukturalnej communitas partia nie mogła akceptować dłużej, niż musiała ze względu na okoliczności, gdyż dążyła do ugruntowania swojej władzy we wszystkich sferach życia. Bolszewicy stali już wówczas na pozycji obrońców panującej rzeczywistości, przeciwko której Majakowski wysuwał ideę rewolucyjnej miŁości. Kilka lat później Łunaczarski wycofywał się ze swoich poglądów, a państwo coraz wyraźniej ingerowało w kwestie seksu, narzucając społeczeństwu tradycyjną moralność i pruderię. Natomiast Majakowski swoich przekonań nie zmienił - romantyczna namiętność pozostawała dla niego kluczową kwestią w myśleniu o stosunkach społecznych. $\mathrm{Na}$ dowód wystarczy wspomnieć fragment drugiego wstępu do poematu Na cały głos z 1930 roku: „Ufam/ i wierzę:/ nigdy mi nie przyjdzie/ w hańbiący umiar/ wzrosnąć” (Majakowski, 1959, s. 468) [„надеюсь верую вовеки не придет/ ко мне позорное благоразумие” (Bo весь голос, w: „Fundamental'naia èlektronnaia biblioteka «Russkaia literatura i fol'klor»”, b.d.)]. To więzi miłości miały wyzwalać, zrównywać i uszczęśliwiać ludzi, to poprzez nie dokonać się miała doczesna, ziemska „Rewolucja Ducha”, którą Majakowski przepowiadał. Bolszewikom zależało na modelowaniu takiej struktury emocjonalnej obywateli, która służyłaby interesom partii i państwa, a więc wpisującej się w rzeczywiste stosunki władzy i utwierdzającej ją; poeta afirmował miłość, życie i świat, były to jednak idee, które miały dopiero w pełni urzeczywistnić się dzięki rewolucji i w tym sensie posiadały potężny ładunek destabilizacyjny. Ich siłą była utopijność, tymczasem w okrutną fizyczną i realną siłę bolszewików nikt już wtedy nie mógł wątpić.

Występując w poprzek linii partii, przeciwstawiając jej rosnącemu cynizmowi i terrorowi własną utopię „Rewolucji Ducha”, Majakowski kontynuował zasadniczo swą wcześniejszą walkę przeciwko Bogu i carowi. Tę walkę nazwać można, za Foucaultem, kontrprowadzeniem, a więc przeciwstawianiem narzuconym formom postępowania własnych dróg, metod, organizacji i celów prowadzenia, przede wszystkim w obszarze trzech ekonomii: posłuszeństwa, zbawienia i prawdy (Foucault, 2010, s. 216). Foucault zauważa, że „mówiąc o kontrprowadzeniu, z powodzeniem można, unikając aury świętości towarzyszącej takiemu czy innemu dysydentowi, analizować aspekty rzeczywistego działania jednostek w ogólnym polu politycznym lub w polu relacji władzy" (Foucault, 2010, s. 213). Zmienne stosunki między Majakowskim oraz jego sojusznikami z kręgów futuryzmu 
i konstruktywizmu a kierownictwem partyjnym (aż po ich kres naznaczony samobójstwem poety) interpretować można właśnie jako stosunki sił w obszarze władzy między ruchami prowadzenia i kontrprowadzenia. Bolszewickiemu odsuwaniu urzeczywistnienia komunistycznej utopii w coraz odleglejszą przyszłość Majakowski przeciwstawiał postulat ciągłej rewolucyjnej walki i pracy; powracające w wierszach analogie między trudem poety a robotnika służyły odcięciu się od podziałów i hierarchii kostniejących w przestrzeni społecznej. Afirmacja własnego wysiłku twórczego pozwalała uniezależnić się od negatywnych opinii oraz od redaktorów gazet i wydawnictw. Podobne skutki przynieść też miały próby zbliżenia z publicznością robotniczą w formie niezapośredniczonych przez partię kontaktów między występującym poetą a jego audytorium. Chodziło tu jednak o coś jeszcze: o reaktualizowanie uniesionej rewolucją communitas. Majakowski znosił pośrednictwo partii między sobą a robotnikami, stawiając się w roli trybuna klasy pracującej i bojownika rewolucji.

Wypowiedzenie posłuszeństwa władzy pastoralnej miało więc dwa wymiary: indywidualny i wspólnotowy. Ten pierwszy etyczne uzasadnienie znajdował w wierności samej rewolucyjnej idei, której partia mogła być ledwie realizatorem; wierności posuniętej aż do mistycznej Rozmowy z towarzyszem Leninem: „przez twoje,/ towarzyszu,/ serce/ i imię/ myślimy,/ oddychamy,/ walczymy,/ żyjemy!” (Majakowski, 1967, ss. 144-145) [„вашим,/ товарищ,/ сердцем/ и именем/ думаем,/ дышим,/ боремся/ и живем!" (Разговор с товарищем Лениным, w: Maiakovskil̆, 1982, s. 449)] - uprzednio skrytykowawszy biurokrację i małostkowość, poeta zwraca się w intymnej relacji do Lenina będącego zmarŁym uosobieniem wartości rewolucji. Empirycznym potwierdzeniem drugiego wymiaru było temporalne zawieszenie porządku codzienności wraz z jego stratyfikacjami pozycji i statusów podczas występów poety przed publicznością, co za Foucaultem nazwalibyśmy zasadą „karnawałowego kontruspołecznienia, odwrócenia stosunków i hierarchii społecznych" (Foucault, 2010, s. 225). Ostatecznym zaś umocowaniem kontrprowadzenia Majakowskiego było jego niesłabnące pokładanie wiary w rewolucję, która przewyższa błędy i nieporozumienia aktualnego prowadzenia ze strony partii i zniesie to prowadzenie, a psychologicznie i intelektualnie znosi je jeszcze przed swoim nadejściem. Kontrprowadzenie Majakowskiego było więc oparte na elementach obecnych w oficjalnej propagandzie i doktrynie bolszewickiej, jednak tak dobranych, złożonych i wzmocnionych, że dających w efekcie postawę zgoła inną od oczekiwanej przez kręgi władzy, związaną z eschatologią anarchokomunistyczną, afirmującą bunt, wyzwolenie i samoistność spoŁeczeństwa wolnych ludzi.

\section{Przemoc i rewolucja}

Z miłością jako główną rewolucyjną siłą i spoiwem nowego, porewolucyjnego społeczeństwa pozornie kontrastuje w poezji Majakowskiego zgoda na rewolucyjną przemoc, zgoda nie tłumiona wstydliwie, lecz wyraźnie manifestowana przez pisarza. Refleksja 
Majakowskiego nad przemocowym charakterem zmiany społecznej stanowi kolejny argument przeciwko potocznej opinii, jakoby autor Fletu kręgosłupa był zagubiony i politycznie naiwny, dlatego warto poświęcić jej nieco uwagi. Zdaniem Parniewskiego, utopię Majakowskiego odróżnia od innych rosyjskich utopii końca XIX i początku XX wieku właśnie jej wojowniczość. Wyraźne akcentowanie nieuniknionego charakteru przemocy oraz jej akceptacja jako środka do stworzenia wspólnego domu całej ludzkości odróżnia poetę nie tylko od utopistów chrześcijańskich, lecz i od Bogdanowa:

„Sołowjow mówi jedynie o potrzebie utrzymania narodów w «posłuszeństwie» w pierwszej fazie tworzenia wspólnego chrześcijańskiego domu, zanim zapanuje królestwo wolności, Bogdanow zaś, nie wyrzekając się przemocy (rewolucji), nie wysuwa jednak na plan pierwszy czynnika siły. Majakowski natomiast nie ma wątpliwości, że w historii tylko przemoc jest jedynym właściwym, koniecznym «krokiem do doskonałości, krokiem ku idealnemu państwu», do «powtórnych narodzin ludzkości». Idea niesprzeciwiania się złu siłą to fałszywa teoria" (Parniewski, 1995, s. 151).

Poparcie dla rewolucyjnej przemocy wiązać można z osobistymi relacjami Majakowskiego z osobami pracującymi w resortach siłowych. Jego najbliższy przyjaciel, powiernik i doradca, Osip Brik, od 8 czerwca 1920 roku do 1 stycznia 1924 roku zatrudniony byt w Czeka, w wydziale zajmującym się walką ze spekulacją gospodarczą. Wysoko postawieni funkcjonariusze służb bezpieczeństwa przez całe lata dwudzieste stanowili część najbliższego otoczenia Majakowskiego oraz Lili i Osipa Brików. Związki między lefowcami a policją polityczną były powszechnie znane; towarzyszy z Czeka twórcy uznawali za bohaterów i awangardę rewolucji, analogiczną do awangardy w dziedzinie sztuki. Od jednego z zaprzyjaźnionych funkcjonariuszy OGPU Majakowski dostał mauzera, za co zrewanżował się w 1927 roku wierszem Żotnierze Dzierżyńskiego. Wydaje się jednak, że zagadnienia rewolucyjnej przemocy w twórczości Majakowskiego nie da się sprowadzić do wpływu niektórych osób spośród kręgu przyjaciół i znajomych.

Według Jangfeldta, „bolszewicka bezkompromisowość” oraz „brutalizacja polityki i języka” pojawiły się w twórczości Majakowskiego po raz pierwszy w 1923 roku, w drukowanym na łamach pisma „LEF” okolicznościowym wierszu z okazji 1 Maja. Padają tam słowa, które przywodzą na myśl nie tylko ostre slogany bolszewickiej propagandy, lecz także fragmenty Katechizmu rewolucjonisty Siergieja Nieczajewa:

„Precz ze słabością!

Niech żyje nienawiść!

Nienawiść milionów wobec setek, nienawiść spoiwem solidarności!"

(cyt. za: Jangfeldt, 2010, s. 250)

„Долой нежность!

Да здравствует ненависть!

Ненависть миллионов к сотням,

ненависть, спаявшая солидарность".

[1-е мая («Поэты...»), w: „Vladimir Maiakovskiĭ. Biblioteka Poèzii”, b.d.]

SLH 2/2013 | str. 356 
Wobec powyższych słów Majakowskiego i obecności w jego bliskim gronie pracowników aparatu bezpieczeństwa Jangfeldt przekonywał, że poeta w istocie „z pewnością nie był krwiożerczy i [...] przeczuwał, że przemoc nie jest żadnym rozwiązaniem" (Jangfeldt, 2010, s. 370). Oczywiście w przypadku Majakowskiego nie ma sensu mówić o „krwiożerczości”; raczej zapewnianie o jej braku, niekiedy wspierane argumentem o naiwności poety, wydaje się zbyt łatwym rozwiązaniem i świadectwem problemu, jaki z akceptacją przemocy przez poetę mają niektórzy jego interpretatorzy. Tymczasem Majakowski zdawał się akceptować przemoc w imię walki o wolne od przemocy, komunistyczne jutro, szczęście i pokój przyniesione pracującym masom na bagnetach ${ }^{11}$. Poparcie rewolucyjnej przemocy, przynajmniej do pewnego stopnia, było wyrazem politycznej trzeźwości, a nie „krwiożerczego” charakteru. Z pewnością zaś stanowiło odbicie wielu podobnych okrzyków, pojawiających się w dyskursie prasowym tego czasu, odbicie zrozumiałe w poezji, która miała być prosta, wolna od ozdobników, łatwo trafiająca do masowego adresata.

Dysonans między przekonaniem o konieczności przemocy a wiarą w dobrą naturę człowieka był przyczyną nieustannych napięć w poezji Majakowskiego. Akceptacja, a chwilami nawet afirmacja przemocy czynią wizję Majakowskiego utopią heroiczną, to znaczy służącą rekonstrukcji świata, a nie uciekaniu od niego, oraz zawierającą program działania i nawołującą do wprowadzenia go w życie (Szacki, 2000, s. 55). A także - utopią polityki, czyli według Jerzego Szackiego aktywnej walki o kształt świata (Szacki, 2000, s. 158), w której, jak zauważył Parniewski, dobro zmaga się ze złem według reguł określonych przez to drugie, może więc sięgnąć po wszelkie środki, by ostatecznie zwyciężyć. W silnie spolaryzowanej, dualistycznej wizji świata można, a czasem nawet trzeba, uciec się do agresji, przemocy i terroru, by ostatecznie zwyciężyć. Przecież one same powinny zniknąć raz na zawsze wraz z triumfem nad przeciwnikiem, który tak określił zasady gry, że nawet szlachetne jednostki muszą sięgać po rozwiązania siłowe. Nawet gdyby nie powiodła się realizacja nowego, wspaniałego świata, to zniszczenie znienawidzonego reżimu, opartego na fałszu i ucisku, w tej perspektywie samo w sobie warte jest podjęcia ryzyka i wysiłku.

Dwadzieścia lat po rewolucji w Rosji, w 1937 roku brytyjski poeta Wystan Hugh Auden dotarł do ogarniętej wojną domową Hiszpanii, by wesprzeć stronę republikańską. Swoje ówczesne stanowisko zawarł w wierszu Hiszpania (Spain), którego fragment pozwolę sobie zacytować:

„Jutro - dla młodych - poeci wybuchowi jak bomby,

Spacery nad jeziorem, tygodnie doskonałej wspólnoty;

Jutro gonitwy na rowerach

Przez przedmieścia w letnie wieczory. Ale dzisiaj walka.

Dzisiaj - rozmyślne zwiększenie ryzyka śmierci,

Świadome przyjęcie winy za nieodzowne morderstwo;

Dzisiaj - trwonienie zdolności

Na płaską, doraźną broszurę i nudne zebranie".

(Hiszpania, w: Auden, 1994, s. 43)

11 Por. Michaił Tuchaczewski, Na zachód! Rozkaz do oddziałów Frontu Zachodniego Nr 1423 (2 lipca 1920 roku, Smoleńsk - tekst drukowany w dzienniku 16. Armii „Krasnoarmiejec”), zwłaszcza fragment: „Na naszych bagnetach przyniesiemy szczęście i pokój masom pracującym” (cyt. za: Davies, 2011, s. 178). 
"To-morrow for the young the poets exploding like bombs,

The walks by the lake, the weeks of perfect communion;

To-morrow the cicycle races

Through the suburbs on summer evenings. But to-day the struggle.

To-day the deliberate increase in the chances of death,

The conscious acceptance of guilt in the necessary murder;

To-day the expending of powers

On the flat ephemeral pamphlet and the boring meeting".

(Spain, w: Auden, 1994, s. 42)

Tłumacz tego wiersza, Stanisław Barańczak, uznał użyte w nim sformułowanie o „nieodzownym morderstwie” (necessary murder) za „totalitarystycznie brzmiące” (Barańczak, 2003, s. 7), przypominał też o późniejszym dystansowaniu się autora wobec własnych słów. We wstępie do wyboru wierszy Audena Barańczak przeciwstawiał sobie stereotypowo ucharakteryzowane figury wiecowego mówcy oraz poety, który siedzi w domu w bamboszach „i wymyśla skomplikowane układy rymów albo zastanawia się nad konstrukcją metafory" (Barańczak, 1994, s. 11). Agitacja, zdaniem Barańczaka, polega na odwoływaniu się „do niekwestionowanych pojęć i wartości zbiorowych”, podczas gdy praca poety to stawianie ich pod znakiem zapytania i zwracanie się do konkretu indywidualnego szczegółu. W pierwszym wypadku mielibyśmy do czynienia z generalizacją i schematycznością, w drugim - ze świadomością języka. Dlatego, konkluduje Barańczak, choć zadanie agitatora „może się wydawać szlachetnym wzięciem na barki współodpowiedzialności za stan społeczeństwa i obowiązku walki o jego dobro, jest w praktyce jakże często pójściem na łatwiznę, wyręczeniem się upraszczającym mitem, stereotypem, chwytliwym sloganem" (Barańczak, 1994, s. 12).

Akceptacja przemocy przez Majakowskiego przy równoczesnym podkreślaniu roli miŁości i godności ludzkiej pokazuje, że zagadnienie zaangażowania - „aby jeszcze raz użyć tego okropnego słowa”, cytując polskiego poetę i tłumacza (Barańczak, 1994, s. 19) - nie da się rozwiązać tak prosto. A to dlatego, że siła „tego okropnego słowa” rozbija dychotomiczną ilustrację kwestionującego przesądy poety i utrwalającego je propagandzisty. Agitator i poeta to w wielu przypadkach nie przeciwstawne bieguny, lecz dwie sprzężone ze sobą funkcje tej samej pracy w materii słowa, które nigdy nie jest elementem autonomicznego systemu językowego, lecz realnym działaniem w różnych obszarach rzeczywistości społecznej. Sam Barańczak jako współtwórca Nowej Fali i autor rozbijających oficjalną nowomowę wierszy dowiódł zresztą, że konstrukcje językowe przesiąknięte są politycznością, a poezja jest znakomitym obszarem ich problematyzowania i rozgrywania. Otwarte poparcie Audena jednej ze ścierających się w Hiszpanii stron, wraz z wszelkimi niełatwymi konsekwencjami, zwłaszcza etycznymi: „świadome przyjęcie winy za nieodzowne morderstwo" (The conscious acceptance of guilt in the necessary murder) - w dodatku poparcie wyrażone $\mathrm{w}$ formie poetyckiej - okazało się w przekonaniu Barańczaka naruszeniem zasady czystości sztuki, podobnie jak rewolucyjne wiersze Majakowskiego 
były jej naruszeniem w oczach ówczesnej krytyki literackiej. Tego typu treści przypominają bowiem, że poezja, sztuka w ogóle, nie jest i nigdy nie była czysta.

Niechęć wobec zaangażowania jest uświadomionym bądź nieświadomym zaangażowaniem, podobnie jak ideologiczne są - niezależnie od ich słuszności - wszelkie krytyki ideologii, oparte niejednokrotnie na doksozofii, czyli ideologii ukrytej pod rzekomo przedideologicznymi terminami „zdrowego rozsądku”, „chłopskiego rozumu” itd. W czasach, o których mowa, kwestie te wysuwały się na pierwszy plan, na co wskazywał już w pierwszych słowach Ulicy jednokierunkowej Walter Benjamin. Pisał on, że wobec ówczesnych przemian społecznych i kulturowych zamykanie aktywności literackiej „w ramach literackich” stanowi wyraz jej „jałowości”. Temu jałowemu, „uniwersalnemu gestowi książki” przeciwstawiał pisarz wpływ literatury „w czynnych wspólnotach”, wpływ oddziałujący za pomocą „ulotek, broszur, artykułów prasowych i plakatów” (Benjamin, 2011, s. 15). Chodziło o taką literaturę, która działa, a nie odcina się od świata w swojej wyobrażonej autonomii. Podobne przekonanie można znaleźć w Dzienniku moskiewskim z podróży Benjamina do stolicy ZSRR na przełomie 1926 i 1927 roku, w zamieszczonej w przypisie pierwszej wersji artykułu Odpowiedź Oscarowi A.H. Schmitzowi, będącego polemiką na temat Pancernika Potiomkina Siergieja Eisensteina. Tę pierwszą wersję tekstu autor opracowywał jeszcze w Moskwie, 26 stycznia 1927 roku; tak odpierał w niej zarzut tendencyjności stawiany omawianemu filmowi:

„Powiedzmy bowiem dobitnie: czy nie byłaby pora skończyć wreszcie z tą zmorą, z tym mieszczańskim straszydłem? Co ma oznaczać ten lament nad pozbawieniem sztuki dziewictwa, odkąd w twórczości dwóch milleniów zostały zdemaskowane wszelkie sublimacje i kompleksy Edypa, pozostałości libidinalne, regresja infantylna. Taka wszakże jest mieszczańska teoria epoki zwyrodnienia: niechże się sztuka szlaja po najciemniejszych choćby zakątkach, byleby tylko in politicis pozostawała przyzwoitym dziewczęciem i nie brała się do marzeń o walce klasowej. Nic z tego: sztuka zawsze o tym marzyła. Ważne jest tylko, że ta tak zwana tendencyjność wraz z przebudzeniem się nowych obszarów świadomości z bardzo skrytego elementu sztuki stała się elementem zupełnie jawnym" (Benjamin, 2012, s. 185).

Dla Benjamina ochrona „dziewictwa”, czyli braku zaangażowania sztuki, stanowiła oczywisty element ideologii, za pomocą której zagrożone mieszczaństwo broniło swego uprzywilejowanego statusu. W tym kontekście zasadności i dramatyzmu nabierają ówczesne rozważania pisarza, czy wstąpić do partii komunistycznej i utracić niezależność, czy pozostać lewicowym outsiderem i narażać się na wchłonięcie przez dominujące mieszczaństwo. Pod względem możliwości rozpowszechniania własnych idei członkostwo w partii pozwalałoby, zdaniem Benjamina, rzutować je „w dane już z góry pole sił”, podczas gdy pozostawanie bezpartyjnym outsiderem stawiało pod znakiem zapytania pożytek z indywidualnej pracy intelektualnej i spychało pisarza ku mieszczaństwu (Benjamin, 2012, s. 127). Choć autor Pasaży ostatecznie nie sięgnął po legitymację partyjną, to nie unikał zaangażowania, dość otwarcie identyfikując się z preferowaną opcją polityczną. Walka cały czas się toczyła i neutralność wobec niej mogła być tylko pozorna, w istocie oznaczając milczącą akceptację reguł gry ustalanych przez dominującą formację i samej tej formacji. 


\section{Polityka sztuki stającej się życiem}

Majakowski występował w imię wartości najwyższych, uniwersalnych, z miłością na czele, a więc wartości charakterystycznych dla communitas, i był gotów walczyć o nie przy użyciu przemocy. Jednakże występował z określonych pozycji klasowych - robotniczych, choć jego samego trudno byłoby określić jako robotnika, i przeciwko określonym klasom - przede wszystkim burżuazji. Taka identyfikacja nierozerwalnie związana ze wskazaniem przeciwnika umieszczała go w samym centrum walki klasowej oraz konfliktów zewnętrznych i wewnętrznych krystalizującego się państwa radzieckiego. Opowiedzenie się po jednej ze stron zmuszało poetę do podjęcia tematu przemocy i wzięcia odpowiedzialności za konsekwencje swojego wyboru. Majakowski poczuwał się do tej odpowiedzialności.

Uniwersalizacja wartości i interesu warstwy robotniczej była nakierowana na jednoznaczny cel: zwycięstwo tej klasy. Poza sprawami gospodarczymi, majątkowymi, prawnymi i obyczajowymi nie mniej ważka walka toczyła się o narzucenie swojej wizji porządku społecznego, swoich kategorii doświadczania i kształtowania wspólnotowości, jej zwartości i linii demarkacyjnych. Reprezentując klasę robotniczą, Majakowski jednocześnie ją tworzyt jako pewną całość o względnie precyzyjnie wytyczonych granicach. W Rosji - inaczej niż w wysoko uprzemysłowionych krajach Zachodu - klasa robotnicza była stosunkowo nieliczna, młoda i bardzo zróżnicowana; była raczej hipostazą klasy lub, za Marksem, klasą w sobie. Będąc jej symbolicznym reprezentantem, rewolucyjny poeta o inteligenckim habitusie zmuszony był z wielu drobnych, oddzielnych grup, z powiązanej podobnym położeniem, lecz nieświadomej zbiorowości, formować klasowy monolit o wspólnym interesie, zdolny do walki o jego realizację. Ta praca ideologiczna była dodatkowo utrudniona szlachecko-inteligenckim pochodzeniem Majakowskiego, który burżuazję zawsze postrzegał raczej jako filisterstwo, ludzi godzących się na zastany byt, żyjących gnuśnie i bezrefleksyjnie. Stratyfikacja społeczna była przez poetę rekonstruowana nie na podstawie marksistowskiej analizy klasowej, lecz z perspektywy estetycznej, przez obserwację stylu życia i dyspozycji przedstawicieli krytykowanej warstwy. Nastawienie w wierszach perspektywy klasowej było tym trudniejsze, że sam Majakowski, dostąpiwszy niewątpliwego awansu klasowego dzięki karierze poetyckiej oraz bliskim związkom z Lili i Osipem Brikami, przejął (choć nie zawsze w sposób zgodny z towarzyską etykietą i konwencjami komunikacyjnymi) wiele ich przyzwyczajeń i nawyków typowych dla wielkomiejskiego, kosmopolitycznego mieszczaństwa. To wszystko nie tylko wymagało od poety wiele wysiłku w zdobywaniu samowiedzy, lecz także wielokrotnie wykorzystywane było przez jego rywali celem jego dyskredytacji i ośmieszenia.

Zadanie, którego Majakowski podejmował się w swojej twórczości, było zatem dwojakie: po pierwsze, zidentyfikowanie klasy robotniczej w zbiorowości obywateli rewolucyjnej i porewolucyjnej Rosji; po drugie, identyfikacja z tą klasą i ustawienie się w roli jej symbolicznego reprezentanta. Te dwa aspekty łączy funkcja władzy symbolicznej, 
władzy reprezentacji, umożliwiającej tworzenie grupy, przemianę klasy w sobie w klasę dla siebie. Wyjaśniał to Pierre Bourdieu:

„W przypadku zbiorowości społecznej, nawet takiej, która jest określana potencjalnie na takiej zasadzie jak chmura [czyli bez łatwo uchwytnych granic - przyp. X.S.], performatywna władza nazywania, prawie zawsze łącząca się z władzą re prez enta cji, powołuje do istnienia w ustanowionej formie, to jest jako zbiorowe ciało, to, co dotąd istniało tylko jako uszeregowany zbiór zestawionych ze sobą jednostek" (Bourdieu, 2008, s. 45; rozstrzelenie X.S.).

Dla Bourdieu rzecznikami grup społecznych, którzy, nie tylko reprezentują je, lecz performatywnie konstruują w rzeczywistości społecznej, są politycy; walka symboliczna dokonuje się w dziedzinie polityki. W przypadku klasy robotniczej w Rosji początku XX wieku taka sytuacja nie mogła w pełni zaistnieć, toteż jej rzecznikami stawali się zawodowi rewolucjoniści oraz artyści i literaci, w tym Majakowski. Od razu trzeba zaznaczyć, że byli to twórcy niezwykle nowatorscy, konsekwentni w uprawianiu „polityki sztuki stającej się życiem”, której zamiar, jak powiada Jacques Rancière, „przedstawia konstrukcję nowych form życia wspólnotowego, a zatem wymazanie siebie jak oddzielnej rzeczywistości" (Rancière, 2007, s. 39). W terminie Rancière’a znakomicie uchwycone zostało nierozerwalne sprzężenie między polityką, sztuką i życiem, które dotychczas analizowaŁem na przykładzie „Rewolucji Ducha” Majakowskiego ze szczególnym uwzględnieniem zagadnień miłości i przemocy jako swoistej komunistycznej heterodoksji i politycznego kontrprowadzenia ${ }^{12}$. Teraz przyjrzę się, jak w praktykach (zwłaszcza praktykach słownych) Majakowskiego przejawiają się konstrukcja i reprezentacja klasy społecznej, a posłużę się w tym celu teorią Bourdieu.

Rosyjska awangarda w przytłaczającej większości określała się po stronie sił rewolucyjnych, zakładając wspólnotę celów między walką o nowe formy życia społecznego a eksperymentowaniem z nowymi formami w sztuce, co z kolei było między innymi skutkiem dyspozycji estetycznej, wpisanej w habitus artystycznej inteligencji. Pod tym względem znaczące jest, że opisując spory studentów na uczelni syna, Aleksandra Majakowska bez wahania utożsamiła różnice estetyczne z klasowymi: „Jedni popierali nową sztukę, drudzy - starą. Jedni byli za sztuką burżuazyjną, drudzy - przeciwko niej” (Majakowska, 1966, s. 40). Bourdieu wyłuszczał, że „punkt widzenia jest pewną perspektywą, cząstkowym, subiektywnym wyobrażeniem (moment subiektywistyczny); jednak jednocześnie jest on opinią, perspektywą przyjmowaną z pewnego punktu, z określonej pozycji w obiektywnej przestrzeni społecznej (moment obiektywistyczny)" (Bourdieu, 2008, s. 36). W dialektyce momentów subiektywistycznego i obiektywistycznego szukać można zrozumienia radykalnych postaw awangardy, które niekiedy, jak w przypadku Majakowskiego, prowadziły do odrzucania własnego pochodzenia i przyjmowania tożsamości klas niższych. To subiektywne poczucie awangardowych artystów wiązało się silnie z obiektywnym zagrożeniem bytu klasy, do której faktycznie należeli. Przy czym sytuacja stawiała ich w trudnym rozdwojeniu: pod względem posiadania kapitału ekonomicznego, najbardziej

12 Por. fragment o Brikach, czyli „nowej rodzinie” Majakowskiego, u Asiejewa: „Nowe i nie odkryte w poezji było im równie drogie, jak nowe i nie odkryte jeszcze w życiu” (Asiejew, 1966, s. 304). 
podstawowego, na ogół zajmowali rzeczywiście stosunkowo niską pozycję w stratyfikacji społecznej, jednakże ich kapitał kulturowy i symboliczny znacznie przewyższał wielkości typowe dla robotników. Subiektywnie więc odczuwając bliskość i solidarność z klasami zdominowanymi, buntując się w obszarze sztuki, artyści często oddalali się od nich kulturowo, tym bardziej, im radykalniejsze były ich zmagania z artystyczną formą.

\section{„Klasa przemawia naszymi stowami”}

Niemal od dziecka zaznajomiony z broszurami i manifestami rewolucyjnymi, dojrzewający w atmosferze niepokojów społecznych, protestów i konspiracji, mający za sobą miesiące młodości spędzone w więzieniu na Butyrkach, pewien swych umiejętności oratorskich, Majakowski bez dłuższych wahań sięgnął po funkcję przedstawiciela klasy, w systemach demokracji liberalnej pełnioną zwykle przez zawodowych polityków. Była to jego indywidualna strategia symboliczna, wyprowadzona z (powyżej ogólnie opisanej) sytuacji niezgodności momentów obiektywistycznego i subiektywistycznego. Wydaje się, że potrzeba utożsamienia się z większą grupą była w Majakowskim silna już wcześniej; spostrzeżenie to dotyczy nie tylko jego działalności partyjnej w wieku nastoletnim, lecz także okresu futurystycznego bezpośrednio przed pierwszą wojną światową. Tak przynajmniej sugeruje krytyk Korniej Czukowski, pisząc, że „Majakowskiego można by nazwać człowiekiem zbiorowości", którą wówczas stanowił dla niego kolektyw futurystów; przez pryzmat ich stosunku do futuryzmu oceniał poeta innych ludzi (Czukowski, 1966, s. 49).

Niezależnie od potrzeby afiliacji grupowej w 1918 roku Majakowskiego znali moskiewscy robotnicy i żołnierze, przed którymi występował na dworcach i fabrycznych dziedzińcach. W latach dwudziestych faktycznie stał się jednym z publicznych reprezentantów klas zdominowanych. „Audytorium robotnicze przyjmowało Majakowskiego bardzo przychylnie" - podkreślała Olga Gzowska, która wielokrotnie deklamowała wiersze poety (Gzowska, 1966, s. 105). Asiejew wspominał, jak recytował twórczość Majakowskiego „W warsztatach remontowych we Władywostoku”:

„przekonałem się z radością, jak bliska jest jego poezja nie tylko mnie, ale i szerokim rzeszom robotniczym. Audytorium robotnicze wysłuchiwało Misterium-buffo z zamarłym oddechem, bez przerw i antraktów. Utwór Majakowskiego został przyjęty z zachwytem" (Asiejew, 1966, s. 310).

Na zorganizowanej na kilka miesięcy przed śmiercią wystawie Dwadzieścia lat pracy Majakowski pod hasłem „MASY nie ROZUMIEJĄ MAJAKOWSKIEGO” („nie” celowo zostato napisane w mniej widoczny sposób) zebrał czasopisma, w których publikowano jego wiersze, od „Prawdy” i „Izwiestii” po tak „egzotyczne” tytuły, jak „Wieś Środkowego Dorzecza Wołgi” z Samary czy „Gwiazda Ałtaju” z Bijska. Artemij Bromberg, komentując tę kolekcję prasy, stwierdzał, że same tytuły prezentowanych na wystawie gazet „stanowiły wystarczający dowód, że pomawianie poety o «niezrozumiałość» pozbawione było wszelkich podstaw" (Bromberg, 1966, s. 428). Zaś aktor Igor Iliński nazywał Majakowskiego

SLH 2/2013 | str. 362 
wielkim wzorcem „człowieka nowej epoki, modelem wielkiego artysty” dla wielu młodych ludzi (Iliński, 1966, s. 226). Owacje wznoszone przez tłumy przychodzące na jego występy w miastach całego imperium przynosiły potwierdzenie pełnienia przezeń funkcji przedstawicielskiej, ponieważ drugą stroną reprezentacji i kreacji klasy społecznej przez jej rzecznika jest akceptacja danego rzecznika przez tworzoną w ten sposób klasę i identyfikacja z nim. Zacytujmy ponownie francuskiego socjologa:

„[...] reprezentowana grupa nie jest niczym więcej jak tym, co ją reprezentuje, czy też samym faktem reprezentacji [...]; czy też, bardziej bezpośrednio, przedstawicielem, jednostką, która ową grupę reprezentuje, w każdym znaczeniu tego słowa, która pojmuje ją mentalnie i wyraża werbalnie, nazywa ją, działa i mówi w jej imieniu, daje jej konkretne ucieleśnienie, uosabia ją w swej osobie i poprzez nią; jednostką, która, czyniąc tę grupę widzianą, czyniąc siebie widzianą zamiast niej, a przede wszystkim przemawiając zamiast niej, powołuje ją do istnienia" (Bourdieu, 2008, s. 45).

Zabieganie Majakowskiego o kontakt z robotniczą publicznością i jej życzliwe przyjęcie było uzasadnione, jeśli pragnął stać się jej przedstawicielem. Dlatego też tak ciężko znosił niechęć ze strony partii i wydawców, negatywne komentarze w prasie, niepochlebne uwagi po występach (recytacje zawsze kończyły się długą sesją pytań oraz opinii publiczności i odpowiedzi artysty). Powtarzające się zarzuty indywidualizmu i niezrozumiałości stawiały pod znakiem zapytania kwestię związku między poetą a klasą robotniczą.

Wróćmy jeszcze do Bourdieu. Znamienne, jak duże znaczenie przywiązuje on do wzajemnego zrozumienia między grupą a jej reprezentantem oraz do wyrażania grupy przez jej reprezentanta za pomocą słowa mówionego i widzialności. Majakowskiego, jako poetę-proroka, poetę-trybuna charakteryzowały właśnie te dwie cechy. Podmiot zbiorowy jego wierszy to przecież proletariat - „towarzysze w masie roboczej” (Poeta robotnik, w: Majakowski, 1957, ss. 99-100) [„Товарищи в рабочей массе” (Поэт рабочий, w: Maiakovskiĭ, 1982, s. 109)], od których poeta różni się jedynie tym, że w swojej pracy musi sobie radzić bez maszyn i fabryk. Zwalczany w dziedzinie literatury, Majakowski-sublokator nieustannie próbował wejść bocznymi drzwiami do polityki, publicznie reprezentując klasę pracującą, mówiąc zamiast niej i jej głosem:

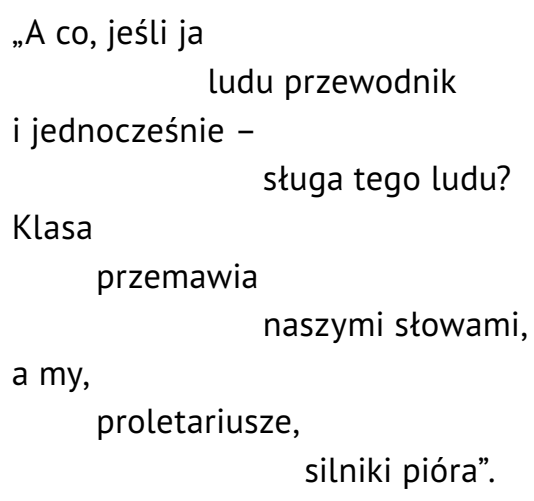

(Rozmowa z fininspektorem o poezji, w: Majakowski, 1957, s. 357) 


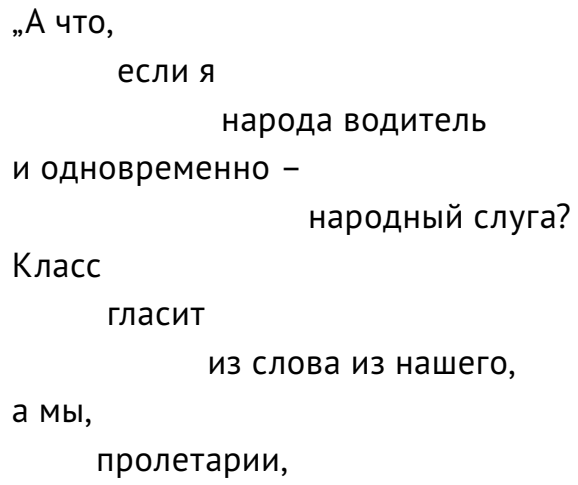

Legitymizacja klasowa własnych poczynań w jego przekonaniu potwierdzała ten fakt i odróżniała go od samozwańców. Majakowski mógł działać słowem poprzez robotników; robotnicy mogli mówić o swoim położeniu, swoim interesie, swojej walce poprzez Majakowskiego. Dzięki tej homologii możliwe było narzucenie ogółowi społeczeństwa własnej wizji świata i podjęcie trudnego wyzwania dokonania zmiany społecznej. Mówiąc krótko: słowo mogło zadziałać.

\section{Trybun i prorok}

„Całym swoim życiem, całą twórczością Majakowski sprzeciwiał się wyobrażeniu o poecie jako kapłanie czy proroku" - pisał Czukowski, odnosząc się do zewnętrznych atrybutów i rekwizytów, takich jak „natchnione włosy”, które Majakowski ściął (Czukowski, 1966, s. 82). Jeśli rzeczywiście kwestia ta była tak ważna dla poety, należałoby rozważyć dlaczego. Być może jego prorocza czy też apostolska postawa przebijała przez coraz bardziej zwyczajną, robotniczą autoprezentację. Rola przedstawiciela klasy robotniczej nie kłóciła się bynajmniej ze wskazywanym wcześniej nastawieniem profetycznym. Antystrukturalne rozprzężenie społecznych podziałów i kategoryzacji w czasie rewolucji i bezpośrednio po niej, reaktualizowane podczas występów Majakowskiego również w późniejszych latach, sprzyjało zawieszaniu czy też rozmiękczaniu ról i statusów społecznych. Ale nie tylko Majakowski wypowiadał się w imieniu klas ludowych, posługując się biblijną stylistyką i przedstawiając eschatologiczne rozumienie biegu zdarzeń. Z jednej strony figura kulturowa proroka w nie mniejszym stopniu niż politycznego reprezentanta powiązana jest z interesami, wartościami i dążnościami rzeczywistej lub potencjalnej grupy społecznej, a z drugiej strony rzecznik danej grupy - aby był skuteczny - posługuje się sugestywną symboliką, a nie zaś naukową abstrakcją. Wprawdzie różnice w samoświadomości, optyce i ideologii mogą prowadzić do dalece odmiennych działań, ale mogą też zostać pogodzone w jednej, w miarę spójnej eschatologicznej wizji - w zależności od całego splotu procesów społeczno-kulturowych. Chiliastyczne postawy rosyjskich marksistów z początku XX stulecia, wywody, w których klasa zdominowana do złudzenia przypomina naród wybrany, a zapowiadana rewolucja ma przynieść koniec historii, unaoczniają płynność tych 
dwóch figur, które rozdzielić można, dokonując analizy na gruncie abstrakcyjnego opisu naukowego, jednak w strumieniu rzeczywistości nie sposób uchwycić granic między nimi.

Współpracowniczka Majakowskiego i autorka haseł do plakatów propagandowych, Rita Rajt-Kowalewa, wspominała po latach z lekką ironią, jak to w latach dwudziestych przy świetle kaganków, w skąpym cieple żelaznych piecyków „burżujek” mocno wierzono, że „zbudujemy elektrownie”, że „będzie miasto”, że „zakwitną ogrody” (Rajt, 1966, s. 179).

Jeśli prorok nie tylko głosi zbliżające się zbawienie, lecz także postuluje podjęcie konkretnych czynów, by ziścił się jakiś wyższy plan, to różnica między nim a reprezentantem klasy namiętnie walczącym o jej emancypację w dużej mierze sprowadza się do odmiennego słownictwa. W Rosji srebrnego wieku nawet najbardziej metafizyczni i religijni myśliciele nie mogli nie dostrzegać nasilających się tarć klasowych i niepokojów społecznych, tak jak partyjnym działaczom i zawodowym rewolucjonistom trudno było zdobyć poparcie społeczne bez posługiwania się religijną frazeologią. Łączenie przez Majakowskiego ról proroka i agitatora nie było wyjątkowe, choć w swojej specyfice niewątpliwie oryginalne. Dopiero wraz z krzepnięciem nowego ładu w początku lat dwudziestych i ze wzmaganiem się bolszewickiego terroru $w$ drugiej połowie dekady rozdźwięk między wcześniej komplementarnymi rolami ukazał się jako nierozwiązywalna w danych okolicznościach społeczno-politycznych sprzeczność. Wyzyskiwali ją przeciwnicy Majakowskiego: proletkultowcy wypierający go z literatury i bolszewicy karczujący jego zapędy w polityce. Przywódcy partyjni zdołali skuteczniej niż poeta osadzić się w roli rzecznika hipostazowanej klasy robotniczej i przez to narzucili jej własne symboliczne ramy i interesy (Bourdieu, 2008, s. 42). Gdy z początkiem lat trzydziestych i umacnianiem się władzy Stalina propaganda coraz rzadziej wzywała do walki o socjalizm, a coraz częściej przedstawiała istniejący ustrój jako spełnioną utopię, wszelki profetyzm z właściwym mu tęsknym patrzeniem w przyszłość i pozostawioną w domyśle refutacją teraźniejszości zaczął być źle widziany i krytykowany.

Jednakże w liminalnym okresie burzliwych przemian, do którego opisu pojęcia roli społecznej można używać tylko w cudzysłowie, aspekty profetyzmu i reprezentacji były jeszcze możliwe do pogodzenia, a stawka walk symbolicznych - „narzucenie prawomocnej wizji świata społecznego i jego podziałów, to jest władza symboliczna jako władza tworzenia świata” (Bourdieu, 2008, s. 45) - zdawała się ciągle w zasięgu ręki. Wobec takiego stanu rzeczy Majakowski starał się chwytać szansę z korzyścią dla swojej poetyckiej sławy. Rozpoznał olbrzymie znaczenie oralności w kulturze klas ludowych, do których chciał dotrzeć, zbieżne z jego zainteresowaniami dźwiękową stroną słowa poetyckiego. $\mathrm{Na}$ tej podstawie próbował zdobyć uznanie robotników bez zrywania z własnym, awangardowym stosunkiem do twórczości, wypracowując typ wiersza oratorskiego i wykorzystując w nowatorskiej strukturze zauważone w ludowej poezji środki: wzorce mnemoniczne, rytmikę słowa mówionego, popularne tematy, wątki i motywy. Uczynił z chłopów, robotników, czerwonoarmistów podmiot zbiorowy swoich wierszy, samemu uznając się za reprezentanta tych grup. Wszystko to składało się na potężny performatywny wymiar 
twórczości poety, w której Majakowski nie tylko opiewał rewolucję - on ją wypowiadał jako stojący w pierwszym szeregu rewolucjonista. Jak pisał Florian Nieuważny:

„Nie należał bowiem do poetów obserwatorów, jako że całą swoją istotą był poetą aktywnym, przekonanym, że poezja może być siłą sprawczą w rzeczywistym świecie. Dla Majakowskiego obcy byt ideał poety-olimpijczyka, obiektywnego wzniosłego klasyka, powściągliwego i pobłażliwego myśliciela. Majakowskiego interesowało wszystko: zachłannie i nieobojętnie współuczestniczył we współczesnym mu życiu, ingerował w nie i próbował je zmienić z pomocą słowa poetyckiego" (Nieuważny, 1995, s. 63).

Zachłanne i nieobojętne współuczestnictwo Majakowskiego w życiu kulturalnym i politycznym nie dało się pogodzić z dążeniami bolszewików do restauracji struktury spoŁecznej po objęciu przez nich władzy. Majakowski popierał ich, ale na pierwszym miejscu stawiał własną rewolucyjną eschatologię i związane z nią kontrprowadzenie. Przedmiotem kontestacji poety były przede wszystkim sprawy „duchowe”, a więc raczej kwestie etyczne i estetyczne niż polityczno-gospodarcze, z wyjątkiem tych problemów, które dotykały go bezpośrednio, jak na przykład rozrost i ociężałość biurokracji. Afirmacja ludzkiej aktywności, przekształcania świata, burzenia barier społecznych oraz uwalniania myślenia z przesądów i zabobonów, która szczególnego wyrazu nabrała w wierszach rewolucyjnych, pozostała do końca trwałą cechą poezji Majakowskiego.

„Oręż krytyki nie może oczywiście zastąpić krytyki orężem; siłę materialną trzeba odpierać materialną siłą - powiadał Marks - wszelako i teoria staje się potęgą materialną, skoro porywa za sobą masy. Teoria zdolna jest porywać masy, gdy tylko dostarcza dowodów ad hominem, gdy tylko staje się radykalna" (Marks \& Engels, 1949, s. 24).

W procesie gwałtownej zmiany społecznej słowo poety zaangażowanego politycznie i uzbrojonego w świadomość własnego warsztatu może mieć niebagatelną moc przekształcania rzeczywistości. Zdaniem Bourdieu, „zdominowani dysponują praktycznym opanowaniem zasad rządzących światem społecznym, praktyczną wiedzą na jego temat. Nazwanie tego świata może wywrzeć na nią teoretyczny efekt - efekt objawienia - albowiem gdy nazywanie jest solidnie ugruntowane w rzeczywistości, wówczas posiada naprawdę twórczą siłę" (Bourdieu, 2008, s. 46).

Ufny w swą umiejętność nazywania świata, Majakowski, choć udzielał się w rozlicznych inicjatywach politycznych i kulturalnych, a w wierszach rewolucyjnych wychwalał czerwonoarmistów walczących z bronią w ręku - wszak: „Dzisiaj/ ma głos/ towarzysz Mauzer” (Lewa marsz, w: Majakowski, 1957, s. 101) [„Ваше/ слово,/ товарищ маузер” (Левый мapu, w: Maiakovskiĭ, 1982, s. 112)] - to w słowie wzniecającym płomienie rewolucji pokładał swe nadzieje na skok do królestwa wolności. To zaangażowanie było czynne, gdyż nie sprowadzało się do epickiego sławienia lub opiewania, a więc brązowienia, lecz wykorzystywało performatywną moc słowa: aktualizowało, a nie petryfikowało rewolucję. Stanowiło też ogromny wysiłek, na który składały się zlecenia na utwory propagandowe i reklamowe, opracowywanie plakatów, prace redakcyjne i edytorskie, wyjazdy służbowe w Związku Radzieckim i za granicę, animacja i integracja środowiska artystycznego, 
prelekcje, wystąpienia, odczyty, udział w publicznych dyskusjach, spotkania z czytelnikami - trudno o dobitniejszy przykład, jak ciężką pracą może być to, co w społecznej nieświadomości uchodzi za przejaw próżności i lenistwa.

W tym miejscu mogę wrócić do przyczyn krytyki wysuwanej pod adresem Majakowskiego przez bolszewickich liderów, przedstawicieli organizacji robotniczych, publicystów i pisarzy wiernych przywództwu partii. Heroiczna, heterodoksyjna komunistyczna utopia „Rewolucji Ducha” i związana z nią inicjatywa kontrprowadzenia, konsekwentne realizowanie polityki sztuki stającej się życiem, profetyczne odchylenie w przyszłość, nierozerwalnie związane z kwestionowaniem obowiązującego status quo i tendencjami antystrukturalnymi, zajęcie wyrazistego stanowiska w konflikcie klasowym i próby uczynienia siebie reprezentantem klas zdominowanych - wszystkie te przekonania i praktyki Majakowskiego musiały stać w opozycji wobec procesów restauracji porządku społecznego, ścisłego wydzielania granic między sztuką a polityką, konsolidacji i stabilizacji systemu władzy, które zachodziły w latach dwudziestych w państwie radzieckim.

Cytowany już Meyerhold pisał o Majakowskim:

„Był prawdziwym rewolucjonistą [...]. Ten człowiek skoncentrował w sobie to wszystko, co nas porusza. Znajdowat się ustawicznie w stanie wielkiego napięcia emocjonalnego, gdyż był człowiekiem dnia dzisiejszego, był poetą-trybunem dźwigającej się klasy. Nie wkładał na siebie togi z napisem: «dzisiaj należy być takim» - był takim od zarania swego życia. Nie było to u niego charakteryzacją ani przywdziewaniem maski, ale autentyczną naturą rewolucjonisty, zarówno w sztuce, jak i w polityce. Dzięki tym cechom wysunął się na czoło swej epoki. Rzecz jasna, że wielu to drażniło. Rozgrywały się wokół niego zacięte walki, zewsząd go szczuto, z widowni padały pytania, świadczące o zupełnym niezrozumieniu. To prawda, że dzielnie stawiał czoło tej nawałnicy, ale z biegiem lat gęstniała wokół niego atmosfera niechęci i nawet wrogości" (Meyerhold, 1966, s. 221).

Zdaniem Meyerholda Majakowski przez całe życie postępował świadomie i konsekwentnie; nie pojawia się żadna sugestia naiwności czy oderwania od rzeczywistości. Podobnie jak inni stronnicy Majakowskiego, reżyser świadczy też o pełnieniu przez poetę funkcji trybuna klasy robotniczej i o rewolucyjnej jedności polityki, sztuki i życia. Jeśli Majakowski miał poparcie nie tylko intelektualnej i artystycznej elity, lecz także mas robotniczych, to kim byli jego wrogowie? Asiejew identyfikuje ich jako

„rozwścieczonych drobnomieszczan, oszołomionych jego żywiołowością, posiedzeniarzy, zleżałych unter-priszybiejewów, którzy swój paradny mundur zamienili na kurtkę, czyczykowów i Podkolesinów, lękających się wszelkich innowacji, wszystkiego, co mogłoby zaniepokoić ich stęchłe gusta, przekonania, nawyki" (Asiejew, 1966, s. 324).

Współcześnie, po lekturze dzieł Bourdieu, można powiedzieć, że walki toczone wokół i o Majakowskiego za jego życia i po śmierci angażowały rozmaite rodzaje kapitału, w tym związany z prestiżem społecznym kapitał symboliczny, którego gromadzenie za pomocą nowatorskich technik, performatywnych gestów i zespolenia życia ze sztuką awangarda uczyniła jedną ze swych podstawowych strategii. Pod tym kątem współczesny badacz Dennis loffe analizował skandal, jaki wybuchł, gdy Majakowski został oskarżony przez 
poetę Josifa Izrailewicza, znanego pod artystycznym pseudonimem Alwiek, i malarza Piotra Mituricza o przywłaszczenie sobie i splagiatowanie pośmiertnych pism Wielimira Chlebnikowa (loffe, 2012). loffe dowodził, że Alwiek i Mituricz mieli dwa cele. Pierwszym było zachwianie wysoką pozycją Majakowskiego w radzieckiej kulturze, czyli rozproszenie jego kapitału symbolicznego wśród innych futurystów i - ogólniej - w sferze publicznej. Następnym celem było wyniesienie na piedestał nieżyjącego już Chlebnikowa i ustanowienie jego wyższości nad Majakowskim, czyli zebranie symbolicznego kapitału wokół postaci zmarłego. Tak zdobyty symboliczny kapitał mógłby pociągnąć za sobą zyski w postaci kapitału społecznego i ekonomicznego: Alwiek i Mituricz mogliby zostać uznani za bohaterskich obrońców prawdy; mogliby też, ze względu na bliskie więzy wiążące obu z Chlebnikowem, zarobić na publikacji jego utworów, które sami posiadali. loffe nazywa to cichym kontekstem skandalu, który wywołali. Możliwość sięgnięcia po tak konkretne korzyści uzasadniała podjęcie ryzyka publicznego ataku na Majakowskiego (loffe, 2012)13.

\section{"A wiersze stoją, ołowiane, ciężkie"}

Na koniec ponownie oddaję głos poecie, który w pisanym na przełomie 1929 i 1930 roku pierwszym wstępie do nieukończonego poematu Na cały głos dokonywał rozliczeń ze swoją przeszłością i teraźniejszością, co czyni ten utwór komplementarnym z wcześniejszym o pięć lat Do domu!, który przywołałem powyżej. „Zdejmij/ okulary-rower, profesorze” (Na cały głos, w: Majakowski, 1959, s. 439) [„Професcop,/ снимите очкивелосипед!" (Во весь голос, w: Maiakovskiĭ, 1965, s. 276)] - pisał Majakowski, zwracając się do przyszłych, żyjących w socjalizmie pokoleń z jeszcze jedną opowieścią o swojej drodze „z pańskich ogrodów/ poezji - kapryśnej baby” (Na cały głos, w: Majakowski, 1959, s. 440) [„из барских садоводств/ поэзии -/ бабы капризной” (Во весь голос, w: Maiakovskil̆, 1965, s. 277)] do walki „pod czerwony sztandar” (Na cały głos, w: Majakowski, 1959, s. 443) [„под красный флаг” (Во весь голос, w: Maiakovskiі̆, 1965, s. 280)]. Poezja zostaje tu wyszydzona jako dziedzina fałszu, ogłupiających, śpiewnych pieśni, estetyzmu i liryczności. Podobnie jak w autobiografii Ja sam z 1922 roku zdyskredytowanej literaturze pięknej przeciwstawione są dzieła Marksa, otwierane „jak w domu własnym/ okiennice” („как в доме/ собственном/ мы открываем ставни”), gdyż ich lekturę uwarunkowały konkretne okoliczności życiowe: „lata roboty/ i dni niedojadania” („года труда/ и дни недоеданий”), wskutek czego „i bez czytania/ było nam wiadomo,/ dokąd należy iść/ i z kim do walki stanąć” (Na cały głos, w: Majakowski, 1959, s. 443) [„HO и без чтения/ мы разбирались в том,/ в каком идти,/ в каком сражаться стане" (Во весь голос, w: Maiakovskiĭ, 1965, s. 280)]. W tej dychotomii podmiot określa się mianem „agitatora,/ przywódcy-gardłacza” („агитатора,/ горлана-главаря”) і przyznaje: „poskramiałem sam siebie/ i stopę/ na gardle/ swej pieśni-m stawiał” („Но я/ себя/ смирял,/ становясь/ на горло/ собственной песне"). Zaznacza też, że nie zależy mu na sławie

13 loffe w oparciu o szereg relacji kwestionuje wysuwane przez Alwieka i Mituricza oskarżenia, a niektóre z nich nazywa wprost absurdalnymi. Również w latach dwudziestych nie dano im wiary. Niemniej wysiłek Alwieka i Mituricza nie poszedł całkiem na marne: zapisali się w pamięci zbiorowej jako obrońcy literackiego dziedzictwa Chlebnikowa. 
i pamięci, a pisanie wierszy nie przyniosło mu pieniędzy. Ważniejsze jest - zwłaszcza gdy weźmiemy pod uwagę, że Majakowski nie był członkiem partii, co wielu mu zarzucało że w przyszłości będzie mógł wskazać „jako/ legitymację bolszewicką” „całe sto tomów/ mych partyjnych książek” („как большевистский партбилет,/ все сто томов/ моих/ партийных книжек”). Jako „agitator” (агuтатор), „przywódca” (главар), uczestnik walk klasowych i autor „partyjnych książek” (партийных книжек) сzuł się więc w pełni uprawniony do reprezentowania klasy robotniczej, występowania i przemawiania w jej imieniu.

Słowa z tych „partyjnych książek” są tu nie tylko obdarzone sprawczością, ale wręcz antropomorfizowane:

„Mój wiersz

przekroczy

przez łańcuchy wieków

ponad głowami

rządów i poetów".

(Na cały głos, w: Majakowski, 1959, s. 441)

„Мой стих дойдет

через хребты веков

и через головы

поэтов и правительств".

(Во весь голос, w: Maiakovskiї, 1965, s. 278)

W przeciwieństwie do poezji przyrównywanej do strzał Amora, startego grosza i światła zmarłych już gwiazd wiersz Majakowskiego ma dotrzeć do przyszłej, socjalistycznej ludzkości dzięki swej własnej trwałości i odporności na upływ czasu niczym budowane przez niewolników rzymskie wodociągi. Jednak właściwa okazuje się metaforyka nie architektoniczna, lecz militarna:

„W kurhanach książek,

które grzebią wiersze,

gdy ostrza strof

przypadkiem odnajdziecie,

żelastwo to

z szacunkiem do rąk bierzcie,

jak starą broń,

lecz jeszcze groźną przecie.

Ja

nie przywykłem

ucha pieścić słowem,

panieńskie uszko,

wdzięczne i różowe,

nie zarumieni się,

zrażone dwuznacznikiem.

Rozwijam wojska stron,

do rewii wciąż gotowe,

SLH 2/2013 | str. 369 
by przejść

przed moich strof

paradnym szykiem.

A wiersze stoją

ołowiane,

ciężkie,

gotowe iść po śmierć

i sławę nieśmiertelną.

Zamarły poematy -

baterie dział zwycięskie,

tytuły ich

to lufy nastawione celnie.

Ta broń,

co zawsze

była mi najmilszą,

gotowa śmiało

ruszyć w bój

z okrzykiem,

zastygła

kawaleria żartów,

milcząc,

podniósłszy rymów

wyostrzone piki.

I wszystkie wojska te,

po zęby uzbrojone,

armie,

co szły

w zwycięstwach długie lata,

aż do ostatniej

moich książek strony

oddaję ci,

proletariuszu świata".

(Na caty głos, w: Majakowski, 1959, ss. 442-443)

„В курганах книг,

похоронивших стих,

железки строк случайно обнаруживая,

вы

с уважением

ощупывайте их,

как старое,

но грозное оружие.

g

yxo

словом

не привык ласкать; 


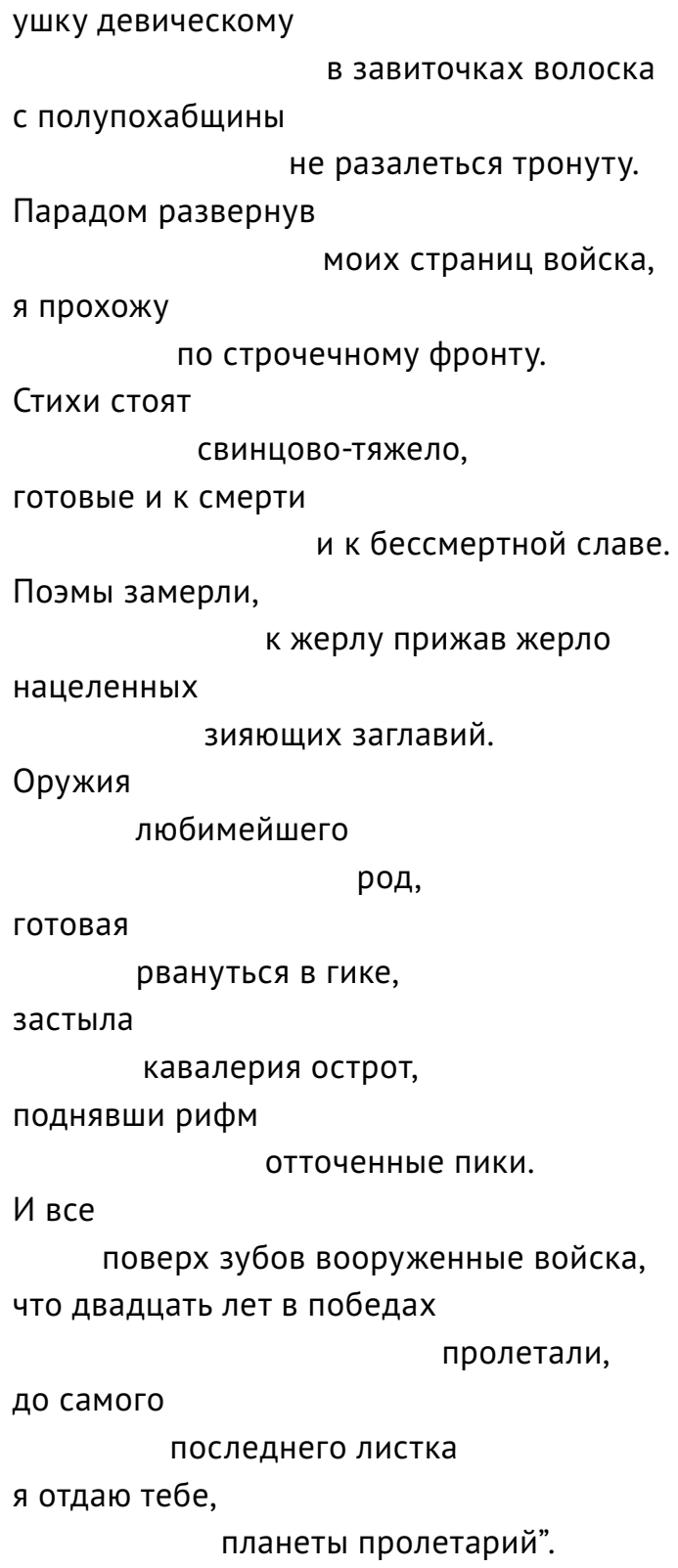

(Во весь голос, w: Maiakovskiї, 1965, ss. 278-279)

Wiersze są bronią, nadal groźnym, ciężkim „żelastwem” (железки): strofy mają ostrza, a rymy „wyostrzone piki” (отточенные пики), strony to wojska („wojska stron”; страниц войска), poematy to „baterie dział zwycięskie”, tytuły - „lufy nastawione celnie” (w oryginale ten fragment brzmi nieco inaczej: „Поэмы замерли,/ к жерлу прижав жерло/ нацеленных/ зияющих заглавий"). Jako takie zdają się być jedynie martwym (są ołowiane, czyli wykonane z metalu związanego ze sferą śmierci już w kulturze starożytnej Grecji, gdy wykonywano z niego katadesmoi, tabliczki z zaklęciami służące czarnej magii) narzędziem, pogrzebanym w „kurhanach książek” (курганах книг). Jednakże okazują się jedynie zamarłe, zastygłe, a nie po prostu nieżywe (nieożywione). Tym, co przywraca je do życia, jest użycie, wypowiedzenie. Przybierają wówczas cechy ludzkie, niczym prawdziwa armia: strofy ustawiają się „paradnym szykiem” (Парадом), dopiero 
co wskrzeszone wiersze stoją "gotowe iść po śmierć/ i sławę nieśmiertelną” („готовые и к смерти/ и к бессмертной славе”), „kawaleria żartów” („кавалерия острот”) milczy w oczekiwaniu rozkazów. Wskrzeszone słowa - nawiązuję do tytułu książki Wiktora Szkłowskiego Воскрешение слова ('Wskrzeszenie słowa') - czekają, by „śmiało/ ruszyć w bój/ z okrzykiem” („рвануться в гике”), przemieniają się w wojska „po zęby uzbrojone”, „co szły/ w zwycięstwach długie lata” („поверх зубов вооруженные”, „что двадцать лет в победах/ пролетали”). Dopiero po ożywieniu armii słów podmiot przekazuje je „proletariuszowi świata" (планеты пролетарий).

Antropomorfizowanie broni jest zjawiskiem starym, wyrażającym bliski, intymny związek wojownika z jego orężem, któremu w ten sposób udzielona zostaje moc niszczenia wroga i obrony swego właściciela. Walczący o swą podmiotowość Majakowski rozciągnął ją na swoje wiersze, swój oręż, symbolicznie zyskując w ten sposób armię sojuszników, by wreszcie rozpuścić rozciągnięte, wyolbrzymione „ja” w anonimowym socjalizmie przyszłości, jeszcze raz utożsamić swój głos z głosem ludzkości. Zatem już nie w pojedynkę „z poezji niebios” rzucał się w komunizm, by jako „fabryka radziecka” dopominać się o zamówienia i oczekiwać państwowej reglamentacji miłości, lecz pewien swojej legitymacji w postaci „stu tomów” „partyjnych książek”, znający idee marksizmu z doświadczenia, a dopiero wtórnie z książek, zmobilizował szeregi swoich słów do kontynuacji zwycięskiego marszu ku komunistycznej przyszłości. Przywrócenie mocy performatywnej własnym słowom, skierowanie ich do rewolucyjnej walki, stłoczenie ludycznych personifikacji i hiperbol stawiają wstęp do utworu Na caty głos tuż obok wierszy rewolucyjnych: „Naszą bronią są nasze pieśni” (Nasz marsz, w: Majakowski, 1957, s. 93) [„Наше оружие - наши песни” (Наш марш, w: Maiakovskiĭ, 1982, s. 103)] - padało w 1918 roku w Naszym Marszu, spinając symboliczną klamrą zmagania poety z bytem.

W najważniejszym ze swych ostatnich utworów, „po zęby uzbrojonych”, „gotowych iść po śmierć" wierszy, Majakowski uczynił dar dla następnych pokoleń. Książki mogą być partyjną legitymacją dla poety, ale dla wierszy są tylko kurhanem, potęgę słowa obracając w wysławianie potęgi. Aby zachować swą moc, słowa, tak jak je rozumiał i jak posługiwał się nimi Majakowski, musiały być w ruchu, krążyć. Dlatego - uzbrojone i zgrupowane w oddziały - podarował je przyszłości.

\section{Bibliografia}

Asiejew, N. (1966). Wspomnienia o Majakowskim. (A. Stern, Tłum.). W Majakowski we wspomnieniach swoich wspótczesnych. Warszawa: Czytelnik.

Auden, W. H. (1994). 44 wiersze. (S. Barańczak, Tłum.). Kraków: Znak.

Barańczak, S. (1994). Wstęp: „Tylko miłość bliźniego i śmierć”. W W. H. Auden, 44 wiersze. (S. Barańczak, Tłum.). Kraków: Znak.

Barańczak, S. (2003). Zamiast wstępu: nota tłumacza. W W. H. Auden, Morze i Zwierciadło. Komentarz do „Burzy” Szekspira. (S. Barańczak, Tłum.). Kraków: a5.

Barthes, R. (2008). Mit dzisiaj. W R. Barthes, Mitologie. (A. Dziadek, Tłum.). Warszawa: Aletheia. 
Benjamin, W. (2011). Ulica jednokierunkowa. (B. Baran, Tłum.). Warszawa: Aletheia. (Frei kolok, T. 89).

Benjamin, W. (2012). Dziennik moskiewski. (B. Baran, Tłum.). Warszawa: Aletheia.

Bourdieu, P. (2008). Co tworzy klasę społeczną? O teoretycznym i praktycznym istnieniu grup. Recykling Idei, (11).

Bromberg, A. (1966). Wystawa Dwadzieścia lat pracy. (Z. Braude, Tłum.). W Majakowski we wspomnieniach swoich współczesnych. Warszawa: Czytelnik.

Burluk, D., Chlebnikow, W., Kruczonych, A., \& Majakowski, W. (1965). Policzek gustom publiczności. W F. Nieuważny (Red.), Włodzimierz Majakowski. (J. Śpiewak, Tłum.). Warszawa: Państwowe Zakłady Wydawnictw Szkolnych.

Czukowski, K. (1966). Majakowski. (S. Pollak, Tłum.). W Majakowski we wspomnieniach swoich współczesnych. Warszawa: Czytelnik.

Davies, N. (2011). Orzeł biały, czerwona gwiazda. (A. Pawelec, Tłum.). Kraków: Znak.

Foucault, M. (1995). Historia seksualności. (T. Komendant, Tłum.) (T. 2: Użytek z przyjemności). Warszawa: Czytelnik.

Foucault, M. (2010). Bezpieczeństwo, terytorium, populacja. (M. Herer, Tłum.). Warszawa: PWN.

Fundamental'naia èlektronnaia biblioteka „Russkaia literatura i fol'klor”. (b.d.). Pobrano 22 styczeń 2013, z http://feb-web.ru

Gzowska, 0. (1966). Moje spotkania z poetą. (S. Pollak, Tłum.). W Majakowski we wspomnieniach swoich wspótczesnych. Warszawa: Czytelnik.

Iliński, I. (1966). Z Majakowskim. (S. Pollak, Tłum.). W Majakowski we wspomnieniach swoich współczesnych. Warszawa: Czytelnik.

Ioffe, D. (2012). The posthumous legacy of Khlebnikov versus Mayakovsky sub specie Avant-Garde performance of scandal: Debating the semiotic pragmatics of Avant-Garde behavior and life-creation. Neohelicon, 39(2), 453-473. doi: 10.1007/s11059-012-0149-6

Jangfeldt, B. (2010). Majakowski. Stawką było życie. (W. Łygaś, Tłum.). Warszawa: W.A.B.

Kołłontaj, A. (2012). Problem małżeństwa i rodziny. Recykling Idei, (13).

Liwszyc, B. (1966). Z książki „Półtoraoki strzelec”. (S. Pollak, Tłum.). W Majakowski we wspomnieniach swoich wspótczesnych. Warszawa: Czytelnik.

Łunaczarska-Rozenel, N. (1966). Łunaczarski i Majakowski. (Z. Braude, Tłum.). W Majakowski we wspomnieniach swoich wspótczesnych. Warszawa: Czytelnik.

MaiakovskiĬ, V. V. (1965). Izbrannye proizvedeniia. V 2-kh tomakh (T. 2). Moskva: Goslitizdat.

MaiakovskiĬ, V. V. (1982). Izbrannye proizvedeniia. V 2-kh tomakh (T. 1). Moskva: Goslitizdat.

Majakowska, A. (1966). Dzieciństwo i młodość Włodzimierza Majakowskiego. (W. Woroszylski, Tłum.). W Majakowski we wspomnieniach swoich wspótczesnych. Warszawa: Czytelnik.

Majakowski, W. (1927). Ja sam. (W. Broniewski, Tłum.). W A. Stern (Red.), Wybór poezyj. Warszawa: Spółdzielnia Księgarska „Książka”.

Majakowski, W. (1957). Poezje. (M. Jastrun, S. Pollak, A. Stern, \& A. Ważyk, Red.). Warszawa: Czytelnik.

Majakowski, W. (1959). Poematy. (M. Jastrun, S. Pollak, A. Stern, \& A. Ważyk, Red.). Warszawa: Czytelnik.

Majakowski, W. (1967). Wam! (S. Pollak, Tłum.). Warszawa: Czytelnik.

Marks, K. (1949). Przyczynek do krytyki heglowskiej filozofii prawa. Wstęp. W F. Engels \& K. Marks, Wybrane pisma filozoficzne 1844-1846. (L. Kołakowski, Tłum.). Warszawa: Książka i Wiedza.

Marks, K., \& Engels, F. (1949). Wybrane pisma filozoficzne 1844-1846. (L. Kołakowski, Tłum.). Warszawa: Książka i Wiedza.

SLH 2/2013 | str. 373 
Meyerhold, W. (1966). Słowo o Majakowskim. (A. Stern, Tłum.). W Majakowski we wspomnieniach swoich wspótczesnych. Warszawa: Czytelnik.

Nieuważny, F. (1995). Od szlochu do szyderstwa (O satyrze Majakowskiego). W W. Olbrych \& J. Szokalski (Red.), Włodzimierz Majakowski i jego czasy. Warszawa: IS PAN.

Parniewski, W. (1995). Majakowski i rosyjska utopia wspólnego domu. W W. Olbrych \& J. Szokalski (Red.), Włodzimierz Majakowski i jego czasy. Warszawa: IS PAN.

Plessner, H. (2008). Granice wspólnoty. Krytyka radykalizmu społecznego. (J. Marecki, Tłum.). Warszawa: Oficyna Naukowa.

Rajt, R. (1966). „Tylko wspomnienia”. (S. Pollak, Tłum.). W Majakowski we wspomnieniach swoich wspótczesnych. Warszawa: Czytelnik.

Rancière, J. (2007). Estetyka jako polityka. (J. Kutyła \& P. Mościcki, Tłum.). Warszawa: Wydawnictwo Krytyki Politycznej.

Sejfullina, L. (1966). Spotkania z Majakowskim. (R. Śliwowski, Tłum.). W Majakowski we wspomnieniach swoich współczesnych. Warszawa: Czytelnik.

Sieriebrow, N. (1966). O Majakowskim. (S. Pollak, Tłum.). W Majakowski we wspomnieniach swoich wspótczesnych. Warszawa: Czytelnik.

Spasski, S. (1966). Moskwa. (R. Śliwowski, Tłum.). W Majakowski we wspomnieniach swoich współczesnych. Warszawa: Czytelnik.

Szacki, J. (2000). Spotkania z utopią. Warszawa: Wydawnictwo Sic!

Szumna, M. (2011). „Krzyk Majakowskiego”. Socrealizm a awangarda. Pamiętnik Literacki, (3).

Tokarska-Bakir, J. (2012). Okrzyki pogromowe. Szkice z antropologii historycznej Polski lat 1939-1946. Wołowiec: Czarne.

Trocki, L. (2012). Od starej rodziny ku nowej. Recykling Idei, (13).

Tyczyński, T. (1995). Chuligan i głodomór. Przyczynek do majakologii. W W. Olbrych \& J. Szokalski (Red.), Włodzimierz Majakowski i jego czasy. Warszawa: IS PAN.

Vladimir Maiakovskiľ. Biblioteka Poèzii. (b.d.). Pobrano 22 styczeń 2013, z http://mayakovskiy.ouc.ru

Woroszylski, W. (1950). Batalia o Majakowskiego. Odrodzenie, (5).

Woroszylski, W. (1965). Życie Majakowskiego. Warszawa: PIW.

Zawadzka, A. (2012). Kawior w sowieckiej ambasadzie. Recykling Idei, (12).

Żegin, L. (1966). Wspomnienie o Majakowskim. (R. Śliwowski, Tłum.). W Majakowski we wspomnieniach swoich wspótczesnych. Warszawa: Czytelnik. 


\section{'You have the floor, Comrade Mauser'. Literature and engagement:}

Mayakovsky's revolutionary poetry as a case study

Abstract: The Russian futurist poet Vladimir Mayakovsky was criticised not only by conservative or moderate critics and writers, but also by Bolshevik ideologists and activists. While moderate authors criticised Mayakovsky's engagement in the communist movement and worried about the waste of his genius, the left-wing writers refused him the place among proletarians due to his improper social background. The article shows the similarities between these two strands of criticism and analyses why communist party was so hostile to the avant-garde revolutionary poetry.

The aim of this text was to investigate why engaged literature is regarded as insincere, unnatural and inappropriate, and to analyse the relations between the poet's words and their specific performative power, the revolutionary abuse and the utopian vision of new world.

Keywords: revolution, struggle, word, literature, utopia, revolutionary abuse and utopian vision of new world. 